
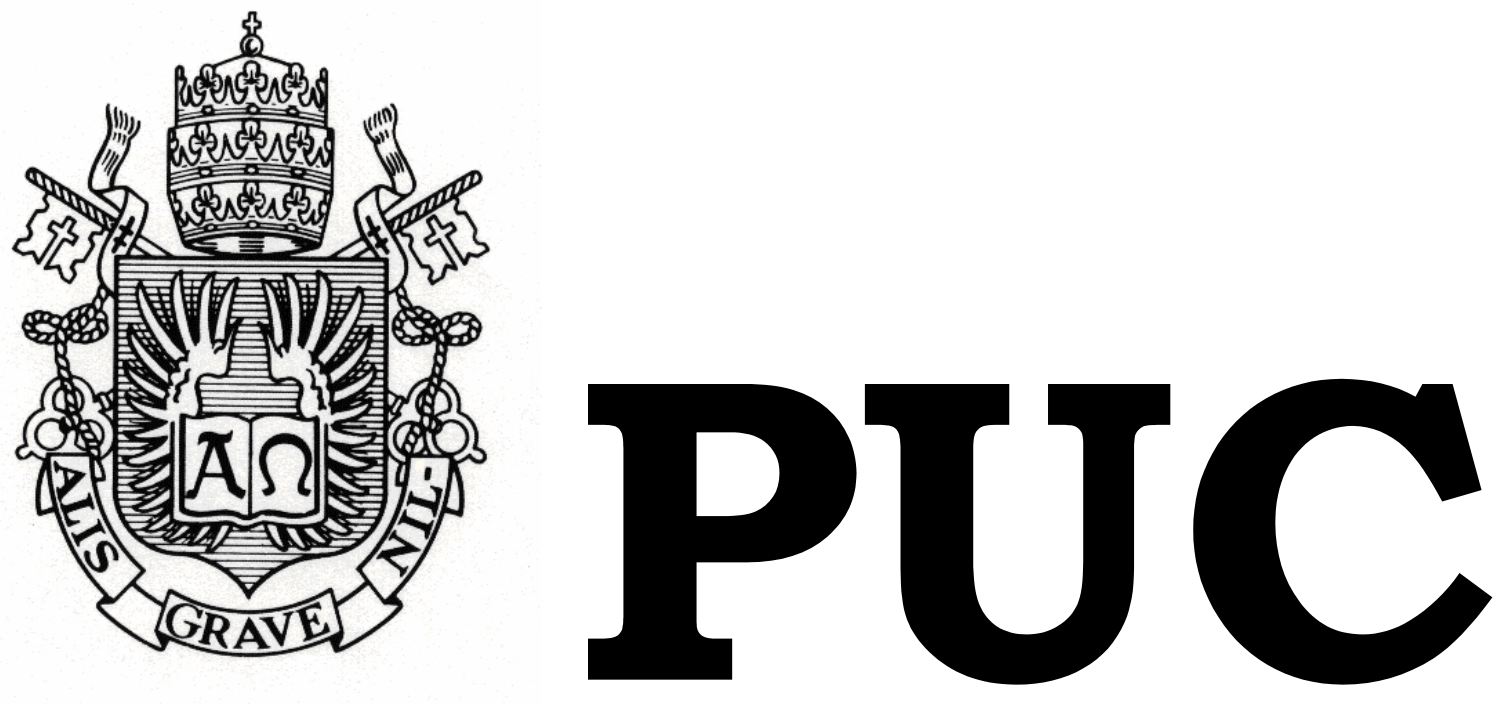

DEPARTAMENTO DE DIREITO

\title{
UNIÃO HOMOSSEXUAL: A NECESSIDADE DE RECONHECIMENTO PELO DIREITO DE FAMÍLIA
}

por

MARIA CLARA ANDRADE SCAPPINI

ORIENTADOR: PROF ${ }^{a}$. KÁTIA REGINA CIOTOLA

2005.1

PONTIFÍCIA UNIVERSIDADE CATÓLICA

DO RIO DE JANEIRO

RUA MARQUÊS DE SÃO VICENTE, 225 - CEP 22453-900

RIO DE JANEIRO - BRASIL 


\section{UNIÃO HOMOSSEXUAL: A NECESSIDADE DE RECONHECIMENTO PELO DIREITO DE FAMÍLIA.}

por

MARIA CLARA ANDRADE SCAPPINI

Monografia apresentada ao Departamento de Direito da Pontificia Universidade Católica do Rio de Janeiro (PUC-Rio) para a obtenção do Título de Bacharel em Direito.

Orientador: Prof ${ }^{a}$. Kátia

Regina Ciotola

2005.1 


\section{Resumo}

A união homossexual não é reconhecida pelo atual ordenamento jurídico, não fazendo parte do Direito de Família brasileiro. Nesse prisma, a questão de maior relevância a ser apresentada no presente trabalho diz respeito ao reconhecimento de uma união entre pessoas do mesmo sexo como merecedora de proteção pelo Estado, no âmbito do Direito de Família.

Até a atual Constituição Federal, todas as outras consagraram o casamento como única forma de constituição de família, o que era seguido pelo legislador infraconstitucional. Além da família decorrente do casamento, a nova ordem constitucional conferiu status de entidade familiar à união estável e às famílias monoparentais.

Ao falar em casamento e união estável a Constituição Federal de 1988 deixou claro que esses modelos de uniões somente são juridicamente reconhecidos quando há diversidade de sexo, sendo assim a união entre homossexuais está excluída da proteção do Direito de Família, podendo ter relevância jurídica em outros planos do Direito.

Nesse contexto, imperioso ressaltar que o presente trabalho tem a finalidade de analisar fatos que ocorreram na sociedade, em especial com relação à evolução do conceito de família, mostrando que em alguns Tribunais brasileiros a semelhança entre as uniões heterossexuais e homossexuais já está sendo observada, devendo o Direito se atualizar, não ignorando um fato social que merece ser regulamentado.

\section{Palavras-Chave}

União homossexual, Direito de Família, união estável, casamento, reconhecimento, princípio da igualdade, afeto. 


\section{Sumário}

1. Introdução

2. Das formas de Família 11

$\begin{array}{ll}2.1 \text { Evolução do conceito de família } & 11\end{array}$

2.2 Direito de Família 16

$\begin{array}{ll}2.3 \text { Casamento } & 18\end{array}$

2.4 União Estável $\quad 21$

3. O problema da inclusão da união homossexual no direito de família

3.1A ineficácia do casamento homossexual: Divergências doutrinárias

3.2Artigo 226, parágrafo $3^{\circ}$. da Constituição Federal: a impossibilidade do reconhecimento de uma união estável entre homossexuais

3.3 Princípio da igualdade e da não discriminação do Direito Brasileiro

3.4. Omissão do Código Civil de 2002 quanto à união de pessoas do mesmo sexo

4. A Atual situação da união homossexual no Direito Estrangeiro e no Direito Brasileiro.

4.1 União homossexual no Direito Estrangeiro

4.2 União homossexual no Direito Brasileiro

4.2.1. Efeitos patrimoniais decorrentes da dissolução inter vivos da união homossexual

4.2.2 Sucessão entre os parceiros homossexuais

4.2.3 Adoção por homossexuais

4.2.4 Legislação Previdenciária e a união homossexual

4.2.5 Legislação estaduais e os homossexuais 57

4.2.6 O Projeto de Lei 1151/95 e seu substitutivo 
5. Conclusão

6. Bibliografia

Anexo I

Anexo II 


\section{Abreviaturas e siglas usadas.}

$\mathrm{CC}-\quad$ Código Civil.

Gn - Gênesis.

TJRJ - $\quad$ Tribunal de Justiça do Rio de Janeiro.

PACS - $\quad$ Pacto Civil de Solidariedade.

STJ - Superior Tribunal de Justiça.

RESP - Recurso Especial.

TJRS - Tribunal de Justiça do Rio Grande do Sul.

SP - $\quad$ São Paulo.

ALERJ - Assembléia Legislativa do Estado do Rio de Janeiro.

ONG - Organização Não Governamental.

INSS - Instituto Nacional de Seguro Social.

PT - Partido Trabalhista. 


\section{1.}

\section{Introdução}

A palavra homossexual, etimologicamente, vem do prefixo grego homo que significa semelhança, igualdade, algo análogo. Já a palavra "sexual" vem do latim sexu e significa "relativo ou pertencente ao sexo". Portanto, juntando as duas palavras podemos chegar à conclusão de que homossexualismo seria a prática sexual entre pessoas do mesmo sexo.

Sob o ponto de vista da Medicina Legal, o homossexualismo, durante a década de 80 , era classificado como sendo uma perversão sexual que leva os indivíduos a sentirem-se atraídos por outros do mesmo sexo, com repulsa absoluta ou relativa para os do sexo oposto. Em alguns livros de renomados autores como Delton Croce e Delton Croce Júnior, a homossexualidade é tratada como "aberração sexual"1.

A homossexualidade pode ser feminina ou masculina, havendo outras designações para definir tais homossexualismos. A masculina é também conhecida como uranismo, pederastia e sodomia. Uranismo é a prática sexual entre homens por falta de mulher; pederastia é a relação anosexual de um homem com uma criança ou menino, já a sodomia seria a prática sexual entre homens adultos. Quanto à homossexualidade feminina são empregados termos como lesbianismo, que é a prática sexual entre duas mulheres que se masturbam mutuamente, safismo, como sendo a prática sexual entre mulheres levada a termo com a sucção do clitóris, e por fim tribadismo, que seria a prática sexual entre mulheres, que consiste no atrito dos órgãos sexuais ${ }^{2}$.

1 CORREIA, Jadson Dias. União civil entre pessoas do mesmo sexo. Disponível em $<$ www.midiaindepedente.org/em/red/2002/02/18021.shtml > . Acesso em 24 jan. 2005.

${ }^{2}$ RIBEIRO, Thaysa Halima Sauáia. Adoções nas células familiares homossexuais (equiparação à união estável). Disponível em < www1.jus.com.br/doutrina/texto.asp?id=3790>. Acesso em $02 \mathrm{de}$ fev. 2005. 
O homossexualismo não é algo recente. A sua prática encontrava-se presente nas antigas civilizações como a Romana, a Egípcia, a Grega e a Assíria, como também em muitos povos selvagens. Em alguns outros povos, o homossexualismo chegou a ser relacionado à religião e à carreira militar, pois a pederastia era atribuída aos deuses Horus e Set, que representavam a homossexualidade e as virtudes militares entre os cartagineses e dórios. Os gregos atribuíam à homossexualidade características como a intelectualidade, estética corporal e ética comportamental, além de representar aspectos religiosos e militares.

Após o advento do Cristianismo, a homossexualidade passou a ser tida como anomalia psicológica, e como sendo um vício baixo e repugnante. Os ingleses, até a recente década de 60 , a consideravam como crime. Em muitos países islâmicos, o homossexualismo é considerado delito até os dias atuais por ser um comportamento contrário aos costumes religiosos ${ }^{3}$.

$\mathrm{Na}$ Idade Média, a homossexualidade estava presente em mosteiros e nos acampamentos militares, mesmo sendo a Igreja, através da Santa Inquisição, a maior perseguidora dos homossexuais.

Em outubro de 1986, o Vaticano se pronunciou a respeito da homossexualidade: "Embora em si não haja um pecado, constitui, no entanto, uma tendência, mais ou menos forte, para um comportamento intrinsecamente mal (sic) do ponto de vista moral". ${ }^{4}$

Atualmente há uma maior aceitação dos homossexuais por parte das sociedades, em especial as ocidentais. A questão é discutida e retratada na televisão, como também no teatro e no cinema. Há a proliferação de movimentos gays em quase toda parte do mundo, buscando um espaço na

\footnotetext{
3 CORREIA, Jadson Dias. União civil entre pessoas do mesmo sexo. Disponível em $<$ www.midiaindepedente.org/em/red/2002/02/18021.shtml > . Acesso em 24 jan. 2005.

${ }^{4}$ BRANDÃO, Débora Vanessa. Parcerias homossexuais: Aspectos jurídicos. São Paulo: Revista dos Tribunais, 2002. p. 37.
} 
sociedade, sem serem submetidos a nenhum tipo de constrangimento e discriminação.

O dia 28 de julho é comemorado por mais de 140 países do mundo como Dia Mundial do Orgulho Gay. Esse dia foi o escolhido pois, no ano de 1969, em Nova Iorque, freqüentadores do bar gay Stonewall Inn, no bairro de Greenwich Village, sofreram agressões e muitos foram levados presos. A polícia entrou no bar alegando que o estabelecimento estava descumprindo as leis sobre a venda de bebidas alcoólicas, e tinham ordens para prender somente funcionários e fregueses vestidos de "drag queen" ou travestis. A multidão que se formou fora do bar se revoltou e começou a protestar contra os abusos dos policiais. Uma semana depois houve uma marcha gay comemorando sete dias do "Levante de Stonewall". Paradas Gays são realizadas em todo o mundo no mês de julho em comemoração a esse $\mathrm{dia}^{5}$.

O Brasil também sofreu a influência desse acontecimento, porém, somente 10 anos depois, com a criação do grupo gay paulista SOMOS, uma entidade organizada que luta pelos direitos dos homossexuais. Seguindo os passos desse grupo foram surgindo outras organizações gays, como o Grupo Gay da Bahia, com sede em Salvador.

Com o aparecimento da aids nos anos 80, várias organizações foram fechadas e a doença era, na maioria das vezes, associada aos homossexuais, considerados grupo de risco. Após esse período, o movimento gay ganhou forças no Brasil, especialmente nos anos 90, com a criação, em 1995, da Associação Brasileira de Gays, Lésbicas e Transexuais (ABGLT), que procurava coordenar ações em todo país. As questões agora abordadas eram a discriminação e o preconceito contra gays e lésbicas ${ }^{6}$.

\footnotetext{
5 MOVIMENTO GAY DE MINAS. História do movimento gay brasileiro. Disponível em $<$ http://www.mgm.org.br/Historia.htm>. Acesso em 07 de abr. 2005.

${ }^{6}$ MOVIMENTO GAY DE MINAS. História do movimento gay brasileiro. Disponível em $<$ http://www.mgm.org.br/Historia.htm>. Acesso em 07 de abr. 2005.
} 
Hoje em dia muitas organizações gays têm o apoio do Ministério da Saúde e Secretarias Estaduais de Direitos Humanos. São realizadas, quase todos os anos, paradas gays por todo o Brasil. No ano de 2004, na cidade de Juiz de Fora, 35 mil pessoas participaram da segunda Parada da Cidadania e do Orgulho GLBT, que durou várias horas. Os participantes demonstraram que a luta contra o preconceito e a marginalização dos homossexuais é de toda sociedade. A multidão seguia pelas ruas debaixo de uma chuva de papel picado que vinha das janelas dos prédios, embalada por músicas e manifestações políticas ${ }^{7}$. Outros movimentos como esse foram realizados e muitos outros já estão programados para acontecer.

A união homossexual, como se pode perceber, sempre esteve presente na história da humanidade, porém nunca foi reconhecida pelo direito. A presente monografia tem o intuito de, através de análises de fatos e dados, e também através de uma análise jurídica, possibilitar o reconhecimento da união entre pessoas do mesmo sexo, sendo merecedora de proteção pelo Direito de Família como entidade familiar.

O conceito de família vem evoluindo, incluindo outras formas de entidades familiares, além da formada pelo casamento. O Direito, como sendo o instrumento capaz de disciplinar a convivência humana, deve acompanhar as modificações que vão surgindo, se mostrando dinâmico, pois se assim não fosse, o seu objetivo não seria alcançado, uma vez que não estaria regrando a vida em sociedade. O capítulo II abordará as formas de família existentes atualmente no Direito brasileiro, como também tratará da evolução do conceito de família, o que possibilitou o reconhecimento de novas formas de família protegidas pelo Direito.

A questão central a ser analisada diz respeito à possibilidade de o Direito de Família reconhecer a união entre pessoas do mesmo sexo. O

\footnotetext{
${ }^{7}$ MOVIMENTO GAY DE MINAS. JF tem a maior parada gay de Minas Gerais. Disponível em $<$ http://www.mgm.org.br/parada_cobertura2004.htm>. Acesso em 07 de abr. 2005.
} 
capítulo III tratará da questão da união homossexual como sendo uma união não reconhecida pelo Direito Brasileiro, pois faltaria um requisito exigido pelo ordenamento vigente para que houvesse a possibilidade de existir um casamento homossexual, ou até mesmo uma união estável homossexual. O mencionado capítulo abordará, também, o princípio da igualdade existente na atual Constituição Federal brasileira, mostrando que esse princípio, com relação aos direitos dos casais homossexuais, não está sendo respeitado.

Por fim, o capítulo IV, apresentará um panorama dos efeitos jurídicos que atualmente são conferidos ao homossexual enquanto casal no Brasil e no mundo, mostrando que se há a possibilidade de existir uma união entre um homem e uma mulher, também será possível uma união entre pessoas do mesmo sexo. 


\section{2.}

\section{Das Formas de Família.}

\section{1}

\section{Evolução do conceito de família.}

A família é a célula da humanidade, pois, por meio dela, houve a possibilidade de formação e desenvolvimento das sociedades. A família é o elo que liga os indivíduos entre si.

Muitos conceituam a família como sendo um fenômeno natural inerente à vontade do homem, porém existem dados que nos possibilitam reconhecer a família como sendo um fenômeno cultural. Nos dias de hoje, não existe a mãe, o pai ou o filho, o que existe é o lugar de pai, de mãe e de filho ${ }^{8}$. Essa questão pode ser mais claramente observada no instituto da adoção, pois uma pessoa pode ocupar o lugar de filho sem ser verdadeiramente filho, ocupar o lugar de pai ou mãe sem que para isso existam laços de consangüinidade, assim como há também a possibilidade de um pai ou uma mãe biológicos não terem condições de ocupar os seus respectivos lugares ${ }^{9}$.

Rodrigo da Cunha Pereira ${ }^{10}$ identifica a Lei do Incesto como sendo a lei fundamental que permitiu a estruturação de todos os ordenamentos jurídicos. O referido autor, citando o psicanalista Freud, argumenta que, se houve a possibilidade de surgir uma lei de incesto, foi porque havia nas pessoas um desejo subjacente, ou seja, um desejo de terem relações sexuais ditas incestuosas. Observa-se que com a proibição de se ter "relações com parentes" foi-se delimitando uma organização familiar segundo aspectos

\footnotetext{
${ }^{8}$ PEREIRA, Rodrigo da Cunha. Direito de Família Contemporâneo. Belo Horizonte: Del Rey, 1997. p. 19.

${ }^{9}$ Ibid. p. 19

${ }^{10}$ Ibid. p.21-25.
} 
puramente culturais e não naturais. Com isso, conclui o autor, que através dessa mencionada Lei foi possível o surgimento das leis da sociedade onde o homem vive, com o estabelecimento de um ordenamento jurídico e a passagem da natureza para a cultura, tornando-se possível estruturar a família.

Num sentido amplo, considera-se família o conjunto de pessoas que descendem de um tronco ancestral comum, acrescentando-se a essa conceituação a figura do cônjuge, e com isso há a inclusão dos filhos do cônjuge, os cônjuges dos filhos, o cônjuge dos irmãos e os irmãos do cônjuge $^{11}$. Sob um aspecto psicológico, a família seria o grupamento de pessoas que vivem sob um mesmo teto, sob a autoridade de uma pessoa ${ }^{12}$. Em um sentido mais estrito, pode-se dizer que a família é o grupo formado pelos pais e pelos filhos ${ }^{13}$. O doutrinador Caio Mário da Silva Pereira comenta que, para efeitos sucessórios, a família seria aquela que compreende as pessoas chamadas por lei a herdar umas das outras, sendo assim, o seu conceito, em razão das tendências do direito positivo, pode ser ampliado ou restringido ${ }^{14}$. Vê-se, portanto, que o conceito de família, assim como a sua extensão, são os que mais se alteram durante toda a história, dependendo do momento e da situação que a sociedade esteja vivenciando.

A família brasileira teve como fundamento os princípios vindos da Roma antiga. A presença da autoridade e do poder do pater caracterizava a família romana patriarcal. O pater era ao mesmo tempo chefe político, sacerdote e juiz, exercendo sobre seus filhos direito de vida e morte. A mulher romana vivia em total subordinação à autoridade marital, passando da condição de filha para a de esposa sem adquirir qualquer autonomia.

\footnotetext{
${ }^{11}$ PEREIRA, Caio Mario da Silva. Instituições de Direito Civil. $14^{\mathrm{a}}$ ed. Rio de Janeiro: Forense, 2004. p.19.

${ }^{12}$ THOMAZ, Thiago Hauptmann Borelli. União homosexual: Reflexões Jurídicas. Disponível em $<$ www1.jus.com.Br/doutrina/texto.asp? $=\mathrm{id}=3930>$. Acesso em 24 de jan. 2005.

${ }^{13}$ PEREIRA, Caio Mário da Silva. Op. Cit.,p. 20.

${ }^{14}$ Ibid. p. 20.
} 
Somente o pater poderia adquirir bens e exercer o poder sobre o patrimônio familiar (domenica potestas).

Essas regras foram sendo modificadas no decorrer dos tempos. Com o Imperador Constantino, surge no direito romano a concepção cristã da família, na qual preocupações de ordem moral predominam.

Antes da elaboração do Código Civil de 1916, no Brasil, as Ordenações Filipinas serviam como regramento normativo em matéria de Direito Civil. As normas de Direito de Família, porém, sofreram uma série de modificações no decorrer do tempo, por meio de legislações esparsas, após a entrada em vigor do Código Civil.

Desde a primeira Constituição Brasileira houve uma grande evolução histórica da família. Na Constituição outorgada em 1824, pelo imperador D. Pedro I, não havia qualquer referência à família ou ao casamento, somente tratava da família imperial e seu aspecto de dotação. A nossa segunda Constituição, agora já republicana, não tratou em especial da família, porém havia expressamente o reconhecimento do casamento civil, não sendo reconhecido o casamento religioso, em razão da separação Igreja/Estado. Foi somente a partir de 1934 que a Constituição Brasileira passou a dedicar um capítulo à família. As demais Constituições, seguindo o mesmo pensamento da Constituição de 1934, reconheciam o casamento indissolúvel como sendo a única forma de se constituir família. Vejamos in verbis:

Constituição Federal de 1937:

Art. 124. A família, constituída pelo casamento indissolúvel, está sob a proteção especial do Estado. Às famílias numerosas serão atribuídas compensações na proporção dos seus encargos.

Constituição Federal de 1946:

Art. 163. A família é constituída pelo casamento de vínculo indissolúvel e terá direito à proteção especial do Estado.

Constituição Federal de 1967: 
Art. 167. A família é constituída pelo casamento e terá direito à proteção dos Poderes Públicos.

Parágrafo $1^{\circ}$. O casamento é indissolúvel.

Constituição Federal de 1969:

Art. 175. A família é constituída pelo casamento e terá direito à proteção dos Poderes Públicos.

Parágrafo $1^{\circ}$. O casamento é indissolúvel (modificado pela Emenda Constitucional n. 9/77, que instituiu o divórcio no Brasil).

Durante muito tempo, a única possibilidade de constituição de família, vista pelo nosso legislador, era através do casamento. Usava-se classificar a família como sendo "legítima", quando oriunda do casamento, e família "ilegítima", sendo esta originária das relações extramatrimoniais. Ainda havia a chamada família adotiva que seria a família criada pelas relações provenientes da adoção tradicional.

As uniões livres e o concubinato não eram vistos como formas de se constituir uma família, ganhando seu espaço somente após grandes discussões doutrinárias e reiteradas decisões jurisprudenciais.

Primeiramente, foram reconhecidos direitos obrigacionais quando do desfazimento da sociedade concubinária, fazendo com que houvesse uma divisão do patrimônio comum do casal, pois este teria sido obtido através do esforço comum. Quando não era possível fazer-se essa divisão, os tribunais concediam à mulher uma indenização por serviços domésticos, com o intuito de não deixá-la desamparada ${ }^{15}$.

Esses efeitos patrimoniais eram tidos como relações obrigacionais criadas pela convivência do casal. Sendo assim, os efeitos de Direito de Família permaneciam afastados. Segundo Carmem Lucia Silveira Ramos, foram sendo atribuídos esses efeitos às situações de fato com o objetivo de

\footnotetext{
${ }^{15}$ RODRIGUES, Silvio. Direito Civil: Direito de Família. $28^{\mathrm{a}}$ ed.. São Paulo: Saraiva, 2004. p. 262.
} 
aliviar as tensões decorrentes de conflitos gerados por essas relações não socorridas pelo direito de família.

Se, num movimento lento e sem uniformidade, a construção jurisprudencial brasileira em nosso século, influenciada pela doutrina, foi pouco a pouco atribuindo efeitos às situações de fato manifestadas como convivência more uxoris, esta postura pode ser vinculada a uma tentativa de aliviar as tensões provocadas pelos conflitos manifestados nestes relacionamentos privados, através da invocação de institutos previstos no próprio sistema, objetivando preservar sua manutenção e, ao mesmo tempo, tentando sobrepujar as deficiências contidas no modelo jurídico consagrado ${ }^{16}$.

A atual Constituição Federal, em seu artigo 226 e parágrafos, veio ampliar as formas de constituição de família. A partir de 1988, não só o casamento civil, mas também a união estável entre um homem e uma mulher e a comunidade formada por qualquer dos seus pais e seus descendestes, passam a ser tidas como entidades familiares e merecedoras de proteção do Estado. Além disso, foram conferidos efeitos civis ao casamento religioso nos termos da lei, consagrando o que antes era disciplinado pela Lei n ${ }^{0}$ 6.015/73 (Lei de Registros Públicos). Com relação a esse tema, mesmo antes da Lei de Registros Públicos, já havia lei dispondo sobre os efeitos civis do casamento religioso, sendo a primeira delas a de $\mathrm{n}^{0} 379$, de 16 de janeiro de 1937 , com modificações posteriores ${ }^{17}$.

A estrutura familiar brasileira está em constante mudança e ao modelo tradicional de família vão sendo aos poucos agregados outros modelos. Atualmente, quando duas pessoas resolvem se unir, o principal objetivo não é ter filhos, mas sim se unirem pelo afeto, respeito e amor.

$\mathrm{O}$ afeto, hoje em dia, é um importante sentimento em uma relação familiar, já se reconhecendo o seu valor jurídico. Com isso a idéia de que essas relações se davam com objetivos e fins patrimoniais, está sendo deixada de lado. A visão ultrapassada de que somente pelo casamento se

\footnotetext{
${ }^{16}$ RAMOS, Carmem Lúcia Silveira. Família sem casamento: Da relação existencial de fato a realidade jurídica. Rio de Janeiro: Renovar, 2000. p. 89.

${ }^{17}$ MONTEIRO, Washington de Barros. Curso de Direito Civil: Direito de Família. $37^{\mathrm{a}}$ ed.. São

Paulo: Saraiva. 2004. p. 101/102.
} 
constitui uma família, deu lugar a essa nova visão que põe em destaque o afeto e o amor entre duas pessoas, fazendo com que esse tipo de união, livre de qualquer formalidade legal imposta pelo matrimônio, seja também reconhecida como uma entidade familiar, como é o caso das uniões estáveis já acima mencionadas.

O Direito, acompanhando as transformações sociais, passou a reconhecer estas uniões e atribuir-lhes conseqüências jurídicas. O que antes era visto como algo negativo passou a ser aceito pela sociedade, não sendo considerado imoral.

\section{2}

\section{Direito de Família.}

O Direito de Família integra a categoria do direito privado, sendo constituído por normas que têm a finalidade de regular as relações pessoais entre os cônjuges, ou entre os ascendentes e os descendentes, como também as relações entre parentes fora da linha reta e as relações patrimoniais que se desenvolvem no seio da família.

O casamento, a filiação, o poder familiar, a adoção, a tutela, a curatela, os alimentos, são institutos do direito de família. São relações pessoais, patrimoniais e assistenciais nas quais o direito de família atua. Com a Constituição Federal de 1988, a união estável passou também a fazer parte do âmbito de proteção jurídica do direito de família.

Todo homem, ao nascer, já faz parte de um organismo familiar. Faz parte desse organismo durante toda a sua existência, mesmo não ficando ligado a uma única família durante toda a sua vida, podendo constituir uma 
nova família. Por esse motivo faz-se necessário que sejam estabelecidas regras de convivência entre os componentes dessa entidade, decorrentes de um entrelaçamento de múltiplas relações estabelecidas entre eles.

O jurista deve, com base na importância que a família tem para a sociedade, defender a entidade familiar evitando, com isso, uma desagregação ${ }^{18}$. As relações familiares merecem proteção do Estado, já que a nossa sociedade é regida por leis que conferem proteção e regulam situações fáticas que ocorrem com os seres humanos. Pela sua importância, a proteção à família está explicitada na nossa Carta Magna, em especial no artigo 226.

A atual Constituição Federal colocou a família formada pela união estável entre homem e mulher e a formada por qualquer dos pais e seus descendentes como sendo merecedoras de igual proteção à que é dada à família constituída pelo casamento. Com isso, o Código Civil de 2002, no capítulo referente ao Direito de Família, aglutinou significativas inovações legislativas e conceituais, especialmente as referentes à união estável ${ }^{19}$, assim como já havia sido feito pela atual Constituição Federal.

Como a evolução dos costumes, houve uma necessidade de ampliação do parentesco, não sendo somente reconhecido o parentesco por consangüinidade e por afinidade. A respeito disso há no Código Civil, especificamente em seu artigo 1593, o reconhecimento de um parentesco civil, que seria dado por outra origem que não a consangüinidade, equiparado-o ao parentesco natural.

As regras do direito de família são obrigatórias e de ordem pública. Sendo assim, em princípio, os particulares não poderão afastar as normas legais que regulamentam os direitos e deveres decorrentes da família ${ }^{20}$. Por esse motivo, muitos juristas entendem que o Direito de Família não deveria

\footnotetext{
${ }^{18}$ MONTEIRO, Washington de Barros. Op. cit., p. 2.

${ }^{19}$ RODRIGUES, Silvio. Op. cit.,p. 15.

${ }^{20}$ MONTEIRO, Washington de Barros. Op. cit., p. 5.
} 
estar inserido no ramo do Direito Privado, mas sim no ramo do Direito Público. Para muitos seria um avanço, e para outros seria um retrocesso, pois estaríamos voltando ao passado onde o Estado controlava todas as relações existentes, impondo suas vontades.

O direito de família também influencia outros ramos do direito, tanto público como privado. $\mathrm{O}$ direito das sucessões leva em consideração a família na parte relativa à sucessão legítima; o direito das obrigações quando os assuntos tratados dizem respeito à doação feita entre ascendente e descendente, como também a compra e venda feita entre eles. No direito penal há a tipificação de delitos contra o casamento, a assistência familiar, o estado de filiação, entre outros. No caso do direito processual, as normas relativas a impedimento e suspeição de juizes, impedimentos de testemunhas e remição na execução, são reflexos de uma influência do direito de família.

Diante disso vê-se a importância do direito de família para a sociedade como um todo, cabendo ao Estado a tarefa de proteger essa entidade, que é a base fundamental de toda a sociedade.

\section{3}

\section{Casamento.}

Existem várias definições que tentam conceituar o que seja casamento. Uma das mais tradicionais, feita por Lafayette, dizia que "o casamento é um ato solene pelo qual duas pessoas de sexo diferente se unem para sempre, sob a promessa recíproca de fidelidade no amor e da 
mais estreita comunhão de vida" ${ }^{21}$. Já, segundo a definição de Clóvis Bevilácqua, "o casamento é um contrato bilateral e solene pelo qual um homem e uma mulher se unem indissoluvelmente, legitimando por ele suas relações sexuais; estabelecendo a mais estreita comunhão de vida e de interesse, e comprometendo-se a criar e educar a prole que de ambos nascer". 22

As definições, de Lafayette e Clóvis Bevilácqua devem ser inseridas no contexto de suas épocas, quando ainda não era permitido o divórcio, sendo o casamento um instituto que deveria durar a vida toda, e o único capaz de legitimar a união entre duas pessoas, diferente do que hoje se reconhece.

Pela definição do nosso ilustre falecido doutrinador Caio Mário: “O casamento é a união de duas pessoas de sexo diferente, realizando uma integração fisiopsíquica permanente". 23

Observando as definições mencionadas, pode-se chegar à conclusão de que, para existir casamento, é preciso que as pessoas envolvidas sejam de sexos diferentes, um homem e uma mulher. Com isso deparamos com um requisito essencial sem o qual não poderia haver casamento. Tal se verifica no casamento de pessoas do mesmo sexo, onde não há o surgimento de efeitos jurídicos.

O atual Código Civil deixa claro, em vários artigos, como, por exemplo, nos artigos 1514, 1517 e 1565, que, para que seja celebrado o casamento, é preciso que os nubentes sejam homem e mulher, não reconhecendo qualquer outra possibilidade.

A Constituição Federal de 1988 tratou do casamento no capítulo VII do título VIII, que diz respeito à família, à criança, ao adolescente e ao

\footnotetext{
${ }^{21}$ PEREIRA, Lafayett Rodrigues. Direitos de Família. Brasília: Fac-similar, 2004. p. 29.

${ }^{22}$ BEVILÁCQUA, Clóvis "Direito de família". In: DINIZ, Maria Helena. curso de Direito Civil Brasileiro. São Paulo: saraiva, 2003. p. 34.

${ }^{23}$ PEREIRA, Caio Mario da Silva. Op. cit., p.53.
} 
idoso. Ao fazer isso, a Constituição deixou claro que pelo casamento há a formação de uma entidade familiar. O Código Civil, ao incluir esse instituto no livro referente ao direito de família, deu o mesmo reconhecimento ao casamento.

Alguns doutrinadores vêem o casamento como sendo um contrato, estabelecido por acordo de vontades entre os cônjuges, tendentes à obtenção de finalidades jurídicas. Essa concepção originou-se no Direito Canônico. Outros dizem que o casamento é uma instituição social, que nasce da vontade dos cônjuges, porém apresenta regras preestabelecidas pelo legislador, com vistas à organização social da união.

Decorrerão da celebração do casamento diversos efeitos jurídicos, sendo o mais importante deles a criação de uma família, conforme preceitua o art. 226, parágrafos $1^{\circ}$ e $2^{\circ}$ da Constituição Federal de 1988. Há também o estabelecimento de um vínculo de afinidade entre cada cônjuge e os parentes do outro. Os deveres de fidelidade recíproca e mútua assistência também são efeitos decorrentes do casamento.

O patrimônio dos cônjuges será afetado uma vez celebrado o casamento. Estes efeitos irão variar de acordo com o tipo de regime adotado pelo casal.

O casamento é um meio de se constituir uma família, ligando duas pessoas que se amam para partilhar uma vida em comum. Nos dias atuais não mais prepondera a idéia de que, com o advento de um filho, duas pessoas devem necessariamente morar e viver juntas. As pessoas se casam com objetivos de manterem uma convivência de auxílio, de integração psicofísica, de assistência mútua, como também de satisfação sexual ${ }^{24}$. Há uma satisfação de amor recíproca e uma comunhão de vida e de interesses ${ }^{25}$. A finalidade de procriação não se apresenta mais como sendo essencial, visto que muitos são os casais que optam por não ter filhos, como

\footnotetext{
${ }^{24}$ VENOSA, Silvio de Salvo. Direito Civil. $3^{\text {a }}$ ed.. São Paulo: Atlas, 2003. v. 6. p. 42.

${ }^{25}$ PEREIRA, Caio Mário da Silva. Op. cit., p. 67.
} 
também há aqueles que não podem ter seus próprios filhos e recorrem à adoção. As pessoas se casam pelo amor que sentem umas pelas outras, pelo respeito e pelo afeto, vindo a formar com isso uma família.

\section{4}

\section{União estável.}

Até a Constituição Federal de 1988, todas as outras Constituições que existiram no Brasil, como já salientado, somente reconheciam o casamento como forma de constituição de uma família. Mesmo assim, as uniões livres entre homens e mulheres sempre existiram. Essas uniões livres não eram reconhecidas pelo direito de família e só encontravam proteção no direito das obrigações. Havia um grande preconceito social em relação a esse tipo de união que não decorria de regular casamento.

O casamento, até o advento da Emenda Constitucional n ${ }^{\circ}$ 9, de 1977, era indissolúvel, sendo assim as pessoas desquitadas não tinham suas novas parcerias reconhecidas.

Com a Constituição de 88, essas uniões livres, antes chamadas concubinárias, passaram a fazer parte do Direito de Família, merecendo a proteção do Estado e sendo reconhecidas como forma de família. Foram, portanto, acolhidas pelo sistema jurídico, novas relações familiares, caracterizando uma grande evolução nesse ramo do Direito.

A Lei 8.971, de 29 de dezembro de 1994, disciplinou o direito dos companheiros a alimentos e à sucessão, seguida da Lei 9.278, de 1996, que tentou regular o parágrafo $3^{\circ}$ do artigo 226 da Constituição Federal de 1988.

Atualmente a união estável se encontra regulamentada no novo Código Civil, mantendo orientação semelhante à da Lei 9.278/96, com 
algumas inovações, como a possibilidade de reconhecimento da união estável entre pessoas que se encontrem separadas de fato.

O artigo 226 da Magna Carta diz que "é reconhecida a união estável entre o homem e a mulher como entidade familiar", fazendo com que a diversidade de sexos seja um pressuposto de fato para a existência de tal união. Diz ainda que "a lei facilitará a sua conversão em casamento", distinguindo, portanto, casamento de união estável.

A união estável se difere do casamento por ser uma sociedade de fato sem se sujeitar a exigências formais, bastando a prova de sua existência para o seu reconhecimento, enquanto que o casamento somente se constitui após a celebração, sendo um ato formal por natureza, provada sua existência pela certidão de casamento, como ensina Leoni Oliveira ${ }^{26}$, representante do Ministério Público do Estado do Rio de Janeiro.

Analisando os artigos do Código Civil sobre união estável, pode-se observar que os deveres de fidelidade, lealdade, respeito, assistência e guarda dos filhos também se encontram presentes, assim como no casamento. Há a previsão de aplicação do regime de comunhão parcial de bens, podendo os companheiros realizar um contrato escrito dispondo de outra maneira. Para que haja a união estável é necessário que a convivência dos companheiros seja notória, duradoura e com o objetivo de constituição de família.

Como se vê o reconhecimento da união estável como entidade familiar é recente. Todas as nossas Constituições anteriores somente reconheciam o casamento como sendo a maneira legítima de formação de uma entidade familiar. Tal pensamento se deve à influência sócio-religiosa, segundo a qual o casamento deveria ter um aspecto procriativo, não sendo levadas em conta outras questões importantes em se tratando de formação de uma entidade familiar. Além da possibilidade de adoção de uma criança,

\footnotetext{
${ }^{26}$ TITOIFF ADVOGADOS. União estável. Disponível em <www.titoiff.adv.br/texto01.htm>. Acesso em 17 de fev. 2005.
} 
há, hoje em dia, métodos anticoncepcionais que fazem com que as pessoas que assim desejam não tenham filhos, deixando de lado por completo a idéia de que somente pode existir e ser reconhecida uma família onde houver a possibilidade de existir filhos.

As transformações ocorridas na sociedade possibilitaram a modificação de tal visão procriativista, dando lugar a uma visão que leva em consideração o afeto e o amor de duas pessoas. O Direito não pode fechar os olhos para as mudanças ocorridas na sociedade, mas, ao contrário, deve acompanhá-las, o que possibilitou que as uniões estáveis fossem regulamentadas e que tivessem a proteção e o reconhecimento do Estado, como sendo uma forma de constituição de família. 


\section{3.}

\section{O problema da inclusão da união homossexual no Direito de Família.}

\section{1}

\section{A ineficácia do casamento homossexual: Divergências doutrinárias.}

Ao conceituar casamento, vimos que todas as definições são unânimes ao dizer que é preciso existir a diversidade de sexos, sendo, portanto, um requisito de validade importante para que se possa celebrar o casamento. A diversidade de sexos é uma exigência de nossa atual legislação, que em vários artigos usa as palavras homem e mulher.

Se as normas legais forem desobedecidas e for realizado um casamento entre homossexuais, o ordenamento jurídico brasileiro não the reconhece a produção e qualquer efeito. Uma parte da doutrina, como Caio Mário da Silva Pereira ${ }^{27}$, entende que tal casamento seria inexistente. Já Silvio Rodrigues ${ }^{28}$ não é adepto desta última teoria e entende que, se celebrado um casamento entre pessoas do mesmo sexo, este vício acarretaria a nulidade stricto senso. Já para os adeptos da teoria do casamento inexistente, o casamento entre homossexuais seria um ato jurídico inexistente.

Para Caio Mário, quando não são observados os requisitos para a celebração do casamento, este se tornará nulo ou anulável, porém se houver a ausência dos pressupostos fáticos, a conseqüência jurídica será a

\footnotetext{
${ }^{27}$ PEREIRA, Caio Mário da Silva. Op. cit., p. 131.

${ }^{28}$ RODRIGUES, Silvio. Op. cit., p. 82.
} 
inexistência do casamento ${ }^{29}$. A nulidade do casamento somente poderá ser decretada em ação própria, já a inexistência poderá ser pronunciada a qualquer tempo pelo juiz, sem ser necessário propor uma ação anulatória. Pontes de Miranda segue essa mesma linha de pensamento, adotando a tese do casamento inexistente.

Como o assunto não é unânime, alguns doutrinadores se posicionaram contra a tese defendida por Caio Mário e Pontes de Miranda $^{30}$, entre eles o já citado Silvio Rodrigues, que critica a idéia de declaração de inexistência dizendo:

Todavia, se foi lavrado o assento de casamento não importa que os nubentes tenham o mesmo sexo, (...). Trata-se de um fato que existe perante o Direito. Ora, para se cancelar aquele registro exige a lei uma ação ordinária, revestia de todas as solenidades reclamadas para a ação de nulidade do casamento, resguardando-se os interesses das partes e da sociedade, pela presença do Ministério Público e do defensor do vínculo. É errôneo dizer que se pode cancelar um registro de casamento por mero despacho judicial, exarado no requerimento inicial de uma das partes, sem audiência de outra e fora de processo ordinário regular. Tal registro só se cancelará após a sentença, com trânsito em julgado, proclamando a nulidade do casamento $^{31}$.

A questão, como se pode perceber, diz respeito à conceituação de ato nulo, ato anulável e ato inexistente, como adiante será analisado.

Os negócios jurídicos podem ser nulos ou anuláveis, segundo a nossa atual legislação. A anulabilidade seria uma sanção mais branda imposta ao negócio jurídico viciado, estando disposta no artigo 171 do Código Civil, com o intuito de proteger o interesse privado do prejudicado ${ }^{32}$. A nulidade, por sua vez, é de ordem pública, diz respeito, portanto, a toda coletividade.

A nulidade pode ser decretada ex officio pelo juiz, podendo também ser pedida a sua declaração por qualquer pessoa interessada ou pelo Ministério Público, não podendo o negócio nulo ser ratificado. Quando se

\footnotetext{
${ }^{29}$ PEREIRA, Caio Mário da Silva. Op. cit., P. 129.

${ }^{30}$ THOMAZ, Thiago Hauptmann Borelli. União homosexual: reflexão jurídica. Disponível em <www1.jus.com.Br/doutrina/texto.asp?id=3930>. Acesso em 02 fev. 2005.

${ }^{31}$ RODRIGUES, Silvio. Op. cit., p. 83.

${ }^{32}$ VENOSA, Sílvio de Salvo. Direito Civil. $4^{\circ}$ ed. São Paulo: Atlas, 2004. V. 1 p. 604.
} 
tratar de anulabilidade, esta somente poderá ser decretada por ação própria ajuizada somente pelos interessados, podendo o negócio anulável ser ratificado.

A doutrina, como já dito acima, lançou mão da teoria dos atos inexistentes, apesar da nossa legislação não consagrar essa classificação. Essa teoria foi criada para justificar a ineficácia absoluta daqueles atos a que faltam requisitos elementares à sua existência ${ }^{33}$. Essa idéia de inexistência nasceu, primeiramente, em matéria de casamento, sendo depois transportada para a teoria geral dos negócios jurídicos.

Muitos criticam essa denominação dizendo que um ato não poderia ser inexistente visto que, se é ato, é porque tem existência. Os adeptos dessa teoria defendem a expressão, alegando que o ato possui aparência, porém não se formou para o Direito. $\mathrm{O}$ ato existiu, mas não para o Direito.

Passando agora ao problema central desse tópico, a questão da nulidade e da anulabilidade se diferencia, não se aplicando ao casamento as regras atinentes à nulidade em geral. Para alguns autores, as nulidades, em matéria de casamento, não podem ser "virtuais",34, estando expressamente previstos na lei os casos de nulidade. Já para aqueles que não reconhecem a teoria do casamento inexistente, quando estivermos diante de um caso em que não se admite o matrimônio, este seria nulo por uma "nulidade virtual", já que não haveria na lei a sua previsão, como é o caso da identidade de sexos.

O casamento é nulo (art. 1548, CC) se for contraído por efermo mental sem o necessário discernimento para os atos da vida civil, ou por infringência de impedimentos, que estão expressos no artigo 1521 do Código Civil. Nesses casos, embora presentes os pressupostos de fato, em virtude de uma situação especial, tal qual a efermidade e a presença de um impedimento, se contraírem casamento, este será declarado nulo.

\footnotetext{
${ }^{33}$ VENOSA, Sílvio de Salvo. Op. cit. p. 605.

${ }^{34}$ PEREIRA, Caio Mário da Silva. Op. cit. p.133.
} 
A sentença de nulidade produzirá efeitos ex tunc, como expresso no artigo 1563 do novo Código Civil, retroagindo à data da celebração do enlace. Sendo nulo o casamento, ele não produzirá os seus efeitos naturais, porém alguns efeitos poderão ser reconhecidos em relação à prole e aos cônjuges, sendo, portanto uma peculiaridade desse tipo de nulidade. Mesmo sendo caso de nulidade ou anulabilidade, produzirá efeitos de válido em razão da boa-fé de ambos ou de um dos contraentes, sendo caracterizado o casamento putativo previsto no artigo 1561 do Código Civil.

Quanto à teoria do casamento inexistente, essa diz respeito à ausência dos pressupostos fáticos ${ }^{35}$. Essa teoria não é recente, tendo sido engendrada por Zachariae, escritor do século XIX. Quando se tratar de inexistência, o juiz pode pronunciá-la a qualquer tempo, sem a necessidade de ser proposta uma ação ordinária anulatória, não produzindo qualquer efeito, nem mesmo provisório, o casamento celebrado.

Com relação ao casamento de pessoas do mesmo sexo, essa união deverá ser considerada inexistente. Não há dúvida de que foi realizada uma cerimônia, porém somente há aparência de casamento, não sendo reconhecido pelo Direito. O ato existiu, mas não para o Direito, sendo, por esse motivo, considerado inexistente. Segundo Caio Mário ${ }^{36}$, a ordem jurídica não pode admitir que existiu o casamento, ainda que para anulá-lo.

O casamento entre homossexuais não poderá produzir efeitos, nem mesmo provisórios, como também não poderá ser declarado putativo, pois o nosso ordenamento não reconhece a união entre pessoas do mesmo sexo. Se fosse reconhecido qualquer efeito a esse tipo de casamento, haveria infringência a uma norma constitucional, que não reconhece a união de pessoas do mesmo sexo como casamento. Partilhando do posicionamento da teoria do casamento inexistente, parece ser esta a que se enquadra melhor ao presente tema, devendo, portanto, ser aplicada.

\footnotetext{
${ }^{35}$ PEREIRA,Caio Mário da Silva. Op. cit. p. 129.

${ }^{36}$ Ibid. p. 131.
} 
Outra questão importante acerca do casamento de homossexuais diz respeito ao posicionamento da Igreja (católica) quanto à possibilidade de existir tal casamento.

A importância da questão deve-se ao fato de que seria um posicionamento contrário à legalização de um possível casamento homossexual, com base nos ensinamentos da Igreja, que só reconhece como válida a união pelo matrimônio de duas pessoas de sexos diferentes. Para a Igreja Católica o matrimônio não é uma união qualquer entre pessoas, mas sim uma união fundada pelo Criador, com uma finalidade.

Em revelações contidas nas narrações bíblicas, diz-se claramente que "o homem e a mulher são iguais enquanto pessoas e complementares enquanto homem e mulher"(Gn 1,27), e que "o homem deixará o seu pai e a sua mãe e unir-se-a à sua mulher e os dois tornar-se-ão uma só carne" (Gn 1,28). Deus, com base nas narrações bíblicas, teria abençoado o homem e a mulher com as palavras: "Sede fecundos e multiplicai-vos" ${ }^{37}$.

As relações homossexuais são tidas, na sagrada escritura, como sendo depravações. As pessoas homossexuais devem, segundo os ensinamentos da Igreja, viver na castidade, sendo tais práticas contrárias à castidade ${ }^{38}$.

Desse modo, a Igreja se coloca como um dos obstáculos ao reconhecimento de um casamento entre pessoas do mesmo sexo já que, por mais que tenhamos vivenciado a separação do Estado da Igreja (da religião), ela ainda influencia um grande grupo de pessoas que seguem a risca seus ensinamentos.

37 CONGREGAÇÃO PARA DOUTRINA DA FÉ. Considerações sobre as propostas de reconhecimento legal das uniões entre homossexuais. Disponível em $<$ http://geocities.yahoo.com.br/amigosdafamiliabr/igreja.htm>. Acesso em 25 de abr. 2005.

${ }^{38}$ Ibid. 


\section{2}

\section{Artigo 226, parágrafo $3^{\circ}$, da Constituição Federal: A impossibilidade do reconhecimento de uma união estável entre homossexuais.}

A Constituição Federal reconheceu a união estável entre um homem e uma mulher como sendo uma forma de constituição de família. Com isso, fez com que esse tipo de união, diferente do casamento, merecesse a proteção do Estado, sendo incluída no Direito de Família.

$\mathrm{O}$ artigo 226, parágrafo $3^{\circ}$, diz expressamente que a união estável somente será reconhecida como entidade familiar se houver diversidade de sexos, ou seja, entre um homem e uma mulher. Ao fazer isso, a Carta Magna não permitiu que fosse reconhecida união estável entre homossexuais, deixando esse tipo de união fora da proteção jurídica do direito de família, mesmo estando as pessoas convivendo a um determinado tempo, com o objetivo de constituir uma família.

Não se pode negar a existência das uniões homossexuais, porém o que se pode negar é a formação de uma entidade familiar do ponto de vista do direito. O casal homossexual pode viver sob o mesmo teto, ter laços afetivos e dividir despesas, surtindo com isso efeitos no mundo jurídico, não efeitos de Direito de Família, mas de Direito Obrigacional.

A união homossexual pode configurar uma sociedade de fato, originando certos direitos de natureza patrimonial. O artigo 981 do Código Civil diz que:

Celebram contrato de sociedade as pessoas que reciprocamente se obrigam a contribuir, com bens ou serviços, para o exercício de atividade econômica e a partilha, entre si, dos resultados.

Sendo reconhecida a existência de uma sociedade de fato, quando houver a dissolução dessa sociedade, por separação ou por morte, os bens havidos pelos esforços comuns devem ser partilhados de forma igualitária. 
A seguinte ementa ilustra essa posição que vem sendo adotada nos tribunais brasileiros:

Direito Civil. Sociedade de Fato. Relação Homossexual. Possibilidade. O direito brasileiro não veda a sociedade de fato entre pessoas do mesmo sexo, sendo necessário, entretanto, a demonstração da existência da contribuição de cada um para formação do patrimônio comum. Revelia. As regras que regem a revelia determinam que sejam considerados verdadeiros os fatos alegados com a inicial. Porém, essa presunção não se verifica quando os próprios documentos trazidos pela parte autora contradizem sua afirmação. Improcedência mantida ${ }^{39}$.

Um outro ponto importante que deve ser observado, diz respeito ao fato de a união estável não poder ser equiparada ao casamento, tendo como argumento o próprio artigo 226 , parágrafo $3^{\circ}$, da Constituição, conforme observa Caio Mário da Silva Pereira ${ }^{40}$. Ao dizer que a lei deverá facilitar a conversão da união estável em casamento, não equiparou esse tipo de entidade familiar à formada pelo matrimônio. Sendo assim, não poderá ser reconhecida como união estável qualquer espécie de união que não possa ser, abstratamente, transformada em casamento, pois do contrário estaria se descumprindo a Carta Magna ${ }^{41}$. Com base nesse argumento, a união estável homossexual seria vedada, pois não haveria a possibilidade da sua conversão em casamento. Há autores, como Marco Aurélio Viana ${ }^{42}$, que alegam que o legislador, ao dizer que a lei deverá facilitar a conversão da união estável em casamento, está fazendo uma opção clara pela relação que se apresenta com aparência de casamento.

Apesar disso, muitos são os que tentam equiparar a união de fato homossexual à união estável, já que ambas são constituídas atualmente tendo por base a relação de afeto. Lendo o artigo 226 , parágrafo $3^{\circ}$, da atual Constituição Federal, perceber-se que quase todos os elementos ali aludidos

\footnotetext{
${ }^{39}$ TJRJ. Apelação Civil n. 2003.001.24718, Rel. Antonio César Siqueira, Rio de Janeiro, 11 nov. 2003.

${ }^{40}$ PEREIRA, Caio Mário da Silva. Op. cit. p. 534.

${ }^{41}$ BRANDÃO, Débora Vanessa Caús. Op. cit. p. 79.

${ }^{42}$ VIANA, Marco Aurélio S. Da união estável. São Paulo: Saraiva, 1999. p. 24.
} 
podem ser usados para se caracterizar uma união entre pessoas do mesmo sexo, com exceção, é claro, da necessidade de serem pessoas de sexos diferentes. Com isso percebe-se que o requisito homem e mulher foi empregado por refletir um pensamento da época, onde havia, ou ainda há, um grande preconceito, e uma enorme dificuldade de se aceitar uma união de natureza diversa.

A autora do livro "União homossexual: O Preconceito \& A Justiça”, Maria Berenice Dias, defende a equiparação da relação homossexual à uma união estável heterossexual, acrescentando também a questão da capacidade procriativa como não sendo essencial para que seja possível o reconhecimento de uma união homoafetiva. Segundo ela:

Passando, duas pessoas ligadas por um vínculo afetivo, a manter uma relação duradoura, pública e contínua, como se casadas fossem, formam um núcleo familiar à semelhança do casamento, independentemente do sexo a que pertencem. A única diferença que essa convivência guarda com a união estável entre um homem e uma mulher é a inexistência do objetivo de gerar filhos. (...) Como a capacidade procriativa ou a vontade de ter prole não são elementos essenciais para que se empreste proteção legal a um par, é de reconhecer-se a incompatibilidade de regra com o preconceito igualitário, que dispõe de maior espectro ${ }^{43}$.

\section{3}

\section{Princípio da igualdade e da não discriminação no direito brasileiro.}

Os princípios constitucionais estão presentes e informam determinada Constituição, estabelecendo diretrizes para o intérprete ${ }^{44}$.Os princípios, assim com as regras, estão englobados no gênero norma jurídica.

Os princípios e as regras se diferenciam, segundo Dworkin e Alexy, qualitativamente, ou seja, do ponto de vista estrutural e lógico ${ }^{45}$. Os

\footnotetext{
${ }^{43}$ DIAS, Maria Berenice. “O preconceito \& a Justiça”. In: BRANDÃO, Débora Vanessa Caús op. cit., p. 81

${ }^{44}$ PEIXINHO, Manoel Messias. A Interpretação da Constituição e Os Princípios Fundamentais: Elementos para uma Hermenêutica Constitucional renovada. $2^{\mathrm{a}}$ ed.. Rio de Janeiro: Lumen Juris, 2000. p. 107.
} 
princípios, segundo essa concepção qualitativa, são considerados um standard que deve ser observado, impedindo que o fenômeno jurídico seja identificado a partir de processos meramente formais, como pressupõe a tese positivista, que separa o Direito da Moral $^{46}$. As regras, por sua vez, são aplicadas a um determinado caso ou não, tanto que, na hipótese de um conflito entre regras, a solução é encontrada utilizando-se os critérios cronológico, hierárquico e da especialidade ${ }^{47}$, de tal forma que a aplicação de uma exclui completamente a possibilidade de incidência da outra sobre o caso. Com relação aos princípios, em caso de conflito, a solução encontrada é outra, pois eles possuem uma dimensão de peso e importância ${ }^{48}$ e não de validade, sendo assim a solução deve ser encontrada levando-se em conta o peso relativo a cada um deles. Os princípios não estabelecem conseqüências jurídicas que devem ocorrer automaticamente, apenas enunciam razões que indicam determinada direção ${ }^{49}$.

O princípio da igualdade está inserido na Declaração dos Direitos do Homem de 1789 (Revolução Francesa), onde, em seus artigos $1^{\circ}$ e $6^{\circ}$, consagram a igualdade de direitos entre os homens e os reconhecem como pessoas perante a $1 \mathrm{ei}^{50}$. In verbis:

Artigo $1^{\circ}$.

Todos os homens nascem livres e iguais em dignidade e direitos. São dotados de razão e consciência e devem agir em relação uns aos outros com espírito de fraternidade.

Artigo $6^{\circ}$.

Todo homem tem o direito de ser, em todos os lugares, reconhecido como pessoa perante a lei.

\footnotetext{
${ }^{45}$ PEREIRA, Jane Reis Gonçalves; LUCAS DA SILVA, Fernanda Duarte Lopes. "A estrutura normativa das normas constitucionais: notas sobre a distinção entre princípios e regras". In: PEIXINHO, Manoel Messias, et alii. Os princípios da Constituição de 1988. Rio de Janiero: Lumen Juris, 2001. p. 08.

${ }^{46}$ Ibid. p. 08.

${ }^{47}$ Ibid. p. 11.

${ }^{48}$ PEREIRA, Jane Reis Gonçalves; LUCAS DA SILVA, Fernanda Duarte Lopes. "A estrutura normativa das normas constitucionais: notas sobre a distinção entre princípios e regras". In: PEIXINHO, Manoel Messias, et alii. Os princípios da Constituição de 1988. Op. cit., p. 09 Ibid. p. 10.

${ }^{49}$ Ibid. p. 09.

50 BOES ORG. Declaração Universal dos Direitos do Homem. Disponível em $<$ http://boes.org/un/brahr-b.html>. Acesso em 19 de abr. 2005.
} 
As constituições americanas, de 1787, e francesa, de 1793, consagraram o princípio da igualdade em seu texto, inaugurando o constitucionalismo moderno ${ }^{51}$.

O princípio da igualdade se desdobra em igualdade formal e igualdade material. A igualdade formal é entendida como sendo a igualdade perante a lei, ou seja, o direito vigente é aplicado de forma igual para todos os destinatários da norma jurídica, sem qualquer distinção, havendo uma única categoria de sujeito de direito. Já a igualdade material é entendida como sendo a igualdade na lei, tratando os iguais igualmente e respeitando as desigualdades.

O principio da igualdade formal sofreu várias críticas por aplicar o direito sem considerações acerca das qualidades pessoais dos destinatários da norma, sendo importante, portanto, a igualdade material, que dá igualdade de condições para todos, levando-se em consideração as características de cada pessoa, prevendo a necessidade de se tratar essas pessoas, quando desiguais, em conformidade com a sua desigualdade ${ }^{52}$. O princípio da igualdade material ganhou importância a partir da proclamação da República de Weimar, em $1920^{53}$.

O publicista francês Duguit entende que a generalidade da lei é insuficiente para a prossecução da igualdade, devendo, com isso, alcançar a própria atuação do legislador ${ }^{54}$, ou seja, a igualdade perante a lei não seria suficiente para gerar a igualdade, sendo importante que o legislador respeite as diferenças, buscando com isso uma verdadeira igualdade, possibilitando um tratamento desigual, se assim entender necessário.

\footnotetext{
51 ABREU, Sérgio. “ O Princípio da Igualdade: a (In) sensível desigualdade ou a isonomia matizada”. In: PEIXINHO, Manoel Messias, et alii. Op. cit.,p. 253.

${ }^{52}$ MORAES, Maria Celina Bodin. Danos à pessoa humana: Uma leitura civil-constitucional dos danos morais. Rio de Janeiro: Renovar, 2003. p. 86.

${ }^{53}$ ABREU, Sérgio. " O Princípio da Igualdade: a (In) sensível desigualdade ou a isonomia matizada”. In: PEIXINHO, Manoel Messias, et alii. Op. cit. P. 256.

${ }^{54}$ Ibid. p. 256.
} 
A Constituição brasileira de 1824 incorporou o princípio da igualdade, porém havia ainda o regime de escravidão que interessava às elites oligárquicas, não existindo uma igualdade real, mas apenas aparente, respeitando-se somente os interesses de um grupo social, excluindo os demais. A Constituição de 1891, após a proclamação da República, manteve em seu texto o princípio da igualdade formal, sendo seguida pelas demais Constituições, até o advento da atual Carta Magna, que trouxe a igualdade material para o texto constitucional ${ }^{55}$.

A atual Constituição Federal, em seu preâmbulo, afirma o princípio da igualdade, assim como em várias disposições de seu texto, estando presente o princípio da igualdade formal, que se traduz na igualdade de todos perante a lei, e o da igualdade material, que confere uma garantia de igualdade na formulação da lei.

$\mathrm{O}$ artigo $5^{\circ}$, caput, diz que todos são iguais perante a lei, sem distinção de qualquer natureza, objetivando, sob o seu aspecto formal, a superação das desigualdades entre as pessoas. Sendo assim, não haveria que se falar em homossexual e heterossexual, pois todos são considerados igualmente pela lei, proibida qualquer discriminação, inclusive por orientação sexual, sendo todos reconhecidos como sujeitos de direitos. A respeito disso, foram criados critérios proibitivos de diferenciação, pois a discriminação é um fator real que deve ser levado em conta. Assim, o artigo $3^{\circ}$, inciso IV, veda a diferenciação por motivo de origem, raça, sexo, cor, idade e quaisquer outras formas de discriminação, dando abertura, nesta última parte, para ser incluída a discriminação por orientação sexual, já que não há previsão expressa no resto do texto constitucional.

\footnotetext{
${ }^{55}$ ABREU, Sérgio. "O Princípio da Igualdade: a (In) sensível desigualdade ou a isonomia matizada”. In: PEIXINHO, Manoel Messias, et alii. Op. cit., p. 258.
} 
A vedação da discriminação por orientação sexual é encontrada expressamente em algumas Constituições Estaduais, como a Constituição do Sergipe ${ }^{56}$ :

Art. $3^{\circ}$ - O Estado assegura por suas leis e pelos atos de seus agentes, além dos direitos e garantias individuais previstos na Constituição Federal e decorrentes do regime e dos princípios que ela adota, ainda os seguintes:

(...)

II - proteção contra a discriminação por motivo de raça, cor, sexo, idade, classe social, orientação sexual, deficiência física, mental ou sensorial, convicção político-ideológica, crença em manifestação religiosa, sendo os infratores passíveis de punição por lei.

Há também a previsão de proibição de diferenciação por orientação sexual na legislação de alguns municípios, como Rio de Janeiro e São Paulo $^{57}$, entre outros. Ainda que a Constituição Federal não diga expressamente que há proibição de discriminação por orientação sexual, alguns Estados brasileiros e alguns municípios, aproveitando-se da abertura deixada no artigo $3^{\circ}$, acabaram por incluir expressamente esse tipo de discriminação em suas Constituições e legislações.

Os homossexuais, segundo o princípio da igualdade formal, são iguais aos heterossexuais perante a lei, devendo ter os seus direitos respeitados e aplicados de forma igualitária. Porém, há casos em que, para se ter igualdade de tratamento, é preciso que sejam observadas as diferenças, pois do contrário não existiria uma igualdade real entre todos. A igualdade material deve ser respeitada e efetivamente aplicada, possibilitando aos desiguais um tratamento igual aos demais. Desse raciocínio, chega-se à conclusão de que a lei elege pessoas como sendo "normais", ou seja, pessoas que vivem suas vidas de uma maneira esperada pela sociedade como um todo. Essa observação é importante, pois, atualmente, na sociedade em que vivemos, os homossexuais são tidos como

\footnotetext{
${ }^{56}$ RIOS, Roger Raupp. O Princípio da Igualdade e a Discriminação por Orientação Sexual: A Homossexualidade no Direito Brasileiro e Norte-Americano. São Paulo: Revista dos Tribunais, 2002. p. 140 .

${ }^{57}$ RIOS, Roger Raupp. Op. cit.,. p. 141.
} 
sendo os desiguais, e para que essa desigualdade se torne uma igualdade é preciso que o legislador preste atenção às diferenças, dando um mesmo tratamento, com relação aos direitos garantidos aos "demais", aos homossexuais.

Maria Celina Bodin de Moraes em reflexão sobre o tema, citou em seu livro "Danos à pessoa humana" um pensamento invocado pelo autor e professor catedrático da Faculdade de Economia de Coimbra, Boaventura de Souza Santos, que diz o seguinte: "As pessoas e os grupos sociais têm o direito a ser iguais quando a diferença os inferioriza, e o direito a ser diferentes quando a igualdade os descaracteriza" ${ }^{98}$.

O tratamento desigual, sob o fundamento do princípio da igualdade material, deve ser avaliado segundo suas características, devendo possuir uma justificação racional, pois se assim não for, impõe-se um tratamento igual, como ordenado pelo princípio da igualdade ${ }^{59}$. Com isso, com relação aos homossexuais, sempre que não houver uma justificação razoável que possibilite o tratamento desigual, deverá ser respeitada a igualdade sem qualquer discriminação quanto à orientação sexual. Em relação a esse tema, Roger Raupp Rios, em seu livro "O princípio da Igualdade e a Discriminação por Orientação Sexual", manifestou-se da seguinte forma:

(...) a dimensão material do princípio da igualdade torna inconstitucional qualquer discriminação que utilize preconceitos ou lance mão de juízos mal fundamentados a respeito da homossexualidade. Vale dizer, em cada uma das questões onde surgir a indagação sobre a possibilidade da equiparação ou da diferenciação em função da orientação sexual, é de rigor a igualdade de tratamento, a não ser que fundamentos racionais possam demonstrar suficientemente a necessidade de tratamento desigual, cujo ônus de argumentação será tanto maior quanto mais intensa for a distinção examinada ${ }^{60}$.

Pessoas homossexuais reclamam, hoje em dia, por "direitos dos homossexuais" e "direito à diferença", exigindo uma igualdade material e

\footnotetext{
${ }^{58}$ MARAES, Maria Celina Bodin. Op. cit., p. 92.

${ }^{59}$ RIOS, Roger Raupp. Op. cit. p. 134.

${ }^{60}$ Ibid. p. 135-136.
} 
não formal, visto que a igualdade formal não levaria em conta a diferença existente, qual seja, a atração por pessoas do mesmo sexo. Um exemplo disso seria o reconhecimento de uma união homossexual ou até mesmo da possibilidade de existir casamento entre pessoas do mesmo sexo, pois atualmente somente pessoas heterossexuais têm reconhecidos esses tipos de união, já que a legislação atual exige a diversidade de sexos. Nesse sentido, com o reconhecimento de uma união estável ou um casamento homossexual, estaria sendo respeitada a igualdade, por também reconhecer o direito ao homossexual de se casar ou estabelecer uma união estável em igualdade de condições com os heterossexuais. Haveria, portanto, o tratamento igualitário entre todos os indivíduos, sendo respeitadas as diferenças sem qualquer tipo de discriminação.

\section{4}

\section{Omissão do Código Civil de 2002 quanto à união de pessoas do mesmo sexo}

O Código Civil atual, vigente desde 11 de janeiro de 2003, não disciplinou em seu texto a união entre pessoas do mesmo sexo, recebendo várias críticas em razão dessa omissão ${ }^{61}$.

O projeto do novo Código foi elaborado no final da década de 60 e início da década de 70, tendo sido entregue ao governo da República em $1975^{62}$. O projeto somente foi aprovado, em 1984, pela Câmara dos Deputados, com modificações, e em seguida encaminhado para o Senado Federal, tendo sido arquivado. Depois de algum tempo, o projeto foi

\footnotetext{
${ }^{61}$ BRANDÃO, Débora Vanessa Caús. Op. cit. P. 87.

${ }^{62}$ O LIBERAL ON LINE. Código Civil está pronto para a votação. Disponível em $<\mathrm{http} / / /$ fiuza.com.br/not13.html>. Acesso em 19 de abr. 2005.
} 
desarquivado, formando-se uma comissão que o aprovou. Seguindo os trâmites previstos na Constituição da época, o projeto foi enviado novamente para a Câmara dos Deputados, a fim de que esta se manifestasse a respeito das emendas feitas ao projeto ${ }^{63}$.

O projeto do novo Código, elaborado antes da vigência da Constituição Federal de 1988, teve por óbvio que se adaptar à nova ordem constitucional antes de ser promulgado. Foi preciso adequar o texto ao novo cenário nacional, principalmente com relação ao Direito de Família, que passou a reconhecer e dar proteção constitucional à união estável e à família formada por qualquer dos pais e seus descendentes, assim como também equiparou os filhos, independentemente de sua origem, conferindo a todos os mesmos direitos e proibindo quaisquer designações discriminatórias relativas à filiação.

Estudiosos do assunto, argumentam que o Código Civil, como lei ordinária que é, não poderia deixar de se submeter às normas Constitucionais, sob pena de ser inconstitucional. A Constituição Federal atual, servindo de base para as alterações feitas no projeto, não reconheceu a união entre pessoas do mesmo sexo, excluindo-a da proteção conferida pelo Direito de Família. Com isso, não poderiam os formuladores do Código dar proteção a uma determinada situação que a própria Lei Maior não reconhece, razão pela qual não regulamentou, assim como também não reconheceu a união estável, nem o casamento entre homossexuais. Com relação a isso, sob o título de "críticas apressadas ou inoportunas", Miguel Reale assim comentou:

Outra crítica apressada e absolutamente sem sentido diz respeito ao fato de o Código Civil não ter cuidado da união estável de pessoas do mesmo sexo. Essa matéria não é de Direito Civil, mas sim de Direito Constitucional, porque a Constituição criou a união estável entre um homem e uma mulher. De maneira que, para cunhar-se aquilo que estão querendo, a união estável dos homossexuais, em

${ }^{63}$ O LIBERAL ON LINE. Código Civil está pronto para a votação. Disponível em $<$ http://fiuza.com.br/not13.html>. Acesso em 19 de abr. 2005. 
primeiro lugar é preciso mudar a Constituição... Não era a nossa tarefa e muito menos a do Senado ${ }^{64}$.

Partilhando do posicionamento acima explicitado, outros doutrinadores, além do já mencionado Miguel Reale, julgam ser necessária uma Emenda Constitucional, pois, somente com isso, poderia haver o reconhecimento de uma união homossexual como entidade familiar, tornando possível a disciplina jurídica dessas uniões pelo Direito de Família, através de leis hierarquicamente inferiores à Constituição, como o Código Civil.

${ }^{64}$ REALE MIGUEL. Críticas apressadas ao novo Código Civil. RT: Revista dos Tribunais. Rio de Janeiro, 1998. $\mathrm{n}^{\circ} .752 .87^{\circ}$. ano . 


\section{4.}

\section{Atual situação da união homossexual no Direito estrangeiro e no Direito brasileiro.}

\section{1}

\section{União homossexual no Direito estrangeiro.}

A questão da união homossexual no mundo atual não se encontra uniforme; há países que assumem uma posição de total aceitação, enquanto outros, principalmente aqueles onde ainda não houve uma libertação em relação às ortodoxas religiões, negaram esse tipo de união.

Pelas diversas posições assumidas pelos países, pode-se dividi-los em três blocos: os liberais, os conservadores e os intermediários ${ }^{65}$.

Os países que se encontram dentro do bloco dos liberais foram os primeiros a legalizar as uniões entre pessoas do mesmo sexo, já os países do bloco conservador assumem uma posição totalmente contrária à dos países situados no bloco liberal. Por ter uma sociedade fortemente ligada à religião, esses países, principalmente islâmicos e muçulmanos, não aceitam a união homossexual, chegando até mesmo a condená-la, por ser contrária aos costumes religiosos. No bloco intermediário encontra-se um maior número de países. Neles a questão da união homossexual ainda está sendo discutida, havendo uma forte tendência em reconhecer algum tipo de efeito jurídico a essas uniões.

A Dinamarca foi o primeiro país a legislar sobre as uniões homossexuais, conferindo a elas alguns tipos de direitos. Em 1986, foram

\footnotetext{
${ }^{65}$ BRANDÃO, Débora Vanessa Caús. Op. cit., p. 40.
} 
concedidos alguns direitos patrimoniais e, em 1989, essas uniões foram legalizadas ${ }^{66}$.

A lei 372/89 (“" Danish Registered Partnership Act”) permitiu que pessoas do mesmo sexo pudessem ter a sua parceria registrada. As parcerias registradas têm quase os mesmos efeitos legais do casamento entre homem e mulher dinamarqueses. Há um dispositivo que diz que as normas sobre formação e dissolução de casamento devem ser igualmente aplicadas para os registros de parceiros. Existe, entretanto, uma pequena diferença entre o casamento e as parcerias registradas. Somente podem ter uma parceria registrada se ambos ou pelo menos um deles for dinamarquês. Isso se deve ao fato de que em muitos países não há ainda o reconhecimento de parcerias homossexuais, com isso, se os parceiros decidirem sair da Dinamarca, devem observar se no país de destino há a previsão legal de união homossexual, pois do contrário a parceria registrada na Dinamarca não terá efeito nesse outro país.

Algumas leis vigentes tiveram que ser emendadas, como foi o caso do Código Penal e da Lei de Tributos. Pessoas casadas ou que tenham uma parceria registrada anteriormente não poderão contrair casamento enquanto o casamento ou a parceria registrada anterior existir, sendo prevista no Código Penal uma prisão de até 3 (três) anos, caso descumprida essa disposição legal.

A corte dinamarquesa utiliza o princípio que veda o enriquecimento sem causa para solucionar os problemas patrimoniais que poderão surgir quando da dissolução de uma parceria, como também aplica a essas uniões a Lei de Formação e Dissolução de Casamento e a Lei de Administração da Justiça $^{67}$.

\footnotetext{
${ }^{66}$ BRANDÃO, Débora Vanessa Caús. Op. cit., p. 41

${ }^{67}$ Ibid. p. 44.
} 
A Noruega, seguindo os passos da Dinamarca, promulgou a Lei 40/93, com vigência no mesmo ano, disciplinando o registro de parcerias homossexuais ("Lov on Registret Partnerskap") 68.

Com relação ao patrimônio dos parceiros registrados, cada um deles será considerado proprietário em partes iguais, do mesmo modo que os cônjuges.

Na Finlândia foi aprovada, em 2001, uma lei que disciplina a união de homossexuais. Pessoas do mesmo sexo, maiores de 18 anos, já podem regulamentar a sua união. A lei, assim como na Dinamarca, concede quase os mesmos direitos do casamento heterossexual aos parceiros homossexuais, porém não permite que o casal homossexual adote uma criança $^{69}$.

A Constituição da África do Sul, do ano de 1996, proíbe qualquer discriminação baseada na orientação sexual, sendo o primeiro país do mundo a proteger a liberdade de orientação sexual como um direito fundamental, porém não chegou a reconhecer uma união entre homossexuais.

Havia, na África do Sul, há algum tempo, um sistema de policiamento sexual, em razão do qual eram perseguidos os comportamentos homossexuais e os direitos humanos eram negados aos gays. Atualmente O Comitê dos Direitos Humanos das Nações Unidas determinou que as leis que proibiam as relações homossexuais violavam o artigo primeiro do Pacto Internacional de Direitos Políticos e Civis, representando uma grande conquista para os homossexuais, em especial para os sul-africanos ${ }^{70}$.

São reconhecidos benefícios de pensão por morte, assistência médica, imigração e direitos sucessórios à parceria doméstica permanente,

\footnotetext{
${ }^{68}$ BRANDÃO, Débora Vanessa Caús. Op. cit., p. 45.

${ }^{69}$ ESTOU FELIZ ASSIM. Uma trajetória contra o preconceito. Disponível em $<$ www.estoufelizassim.hpg.ig.com.br/cronologia6.html>. Acesso em 01 mar. 2005.

${ }^{70}$ BRANDÃO, Débora Vanessa Caús. Op. cit., p. 61.
} 
mesmo não havendo o reconhecimento de uma união homossexual propriamente dita.

Em outros países do continente africano, como Angola, Botsuana, Moçambique, Namíbia e Zâmbia, as práticas homossexuais são consideradas ilegais.

Nos Estados Unidos, os seus estados não são unânimes em relação ao reconhecimento das uniões homossexuais. Algumas cidades estão elaborando registros para as parcerias homossexuais, sendo São Francisco uma dessas cidades. O Estado da Geórgia, por outro lado, aprovou uma lei proibindo expressamente o reconhecimento de parcerias homossexuais.

Algumas cidades concedem benefícios domésticos, entre eles direitos trabalhistas aos parceiros de empregados de empresas. O número de empresas que concedia esse tipo de direito aos parceiros aumentou significantemente do ano de 1990 para o ano de $1995^{71}$. São reconhecidos também alguns direitos relativos ao patrimônio, seguro saúde e outros, especialmente pela cidade de Nova Iorque e São Francisco. Em Nova Iorque, a assembléia estadual aprovou, em maio de 2002, uma lei que reconhece a parceria entre homossexuais, visando com isso beneficiar os parceiros das vítimas do atentado terrorista de 11 de setembro ${ }^{72}$.

No Havaí, desde 1991, há um processo tramitando na justiça de três casais homossexuais contra o estado, por lhes ter sido negada licença para casamento. Sendo vencidos em primeira instância, interpuseram recurso ao Tribunal local, tendo este lhe negado provimento. Porém em 1993, a Suprema Corte local aceitou novo recurso sob o fundamento de que negar uma licença para casamento a casais homossexuais seria violar a emenda da Constituição americana que garante igualdade a todos. Houve um novo

\footnotetext{
${ }^{71}$ BRANDÃO, Débora Vanessa Caús. Op. cit., p 60.

${ }^{72}$ ESTOU FELIZ ASSIM. Uma trajetória contra o preconceito. Disponível em $<$ www.estoufelizassim.hpg.ig.com.br/cronologia6.html>. Acesso em 01 mar. 2005.
} 
julgamento que acabou por conceder a licença para os casais se casarem. A decisão ainda está sujeita a um novo recurso ${ }^{73}$.

Um projeto de lei, chamado Ato de Defesa do Casamento, tramita no Congresso norte americano, e define, pela primeira vez, casamento como sendo a união entre pessoas de sexos opostos. Se esse projeto for aprovado e promulgada a lei, o reconhecimento do casamento entre homossexuais não será possível, porém não excluirá a possibilidade de haver um regramento jurídico sobre as relações de pessoas do mesmo sexo ${ }^{74}$.

$\mathrm{O}$ atual presidente norte americano George W. Bush se mostra contrário ao reconhecimento de uma união homossexual, chegando até a ameaçar estimular uma emenda constitucional que proíba o casamento gay, visando frear a tendência dos tribunais de proferir sentenças favoráveis à legalização do casamento homossexual. Em um pronunciamento feito em 2004 ele disse:

"Se os tribunais insistem em querer impor a sua vontade arbitrária ao povo, a única alternativa será a do processo constitucional. Nossa nação tem de defender o aspecto sagrado do matrimônio" ${ }^{\text {"75 }}$.

Para que as uniões homossexuais sejam reconhecidas por lei é preciso que pelo menos cinco estados aceitem legalizá-las. Caso contrário, o presidente, através de um decreto federal, pode vetar leis nos estados onde é permitido o casamento homossexual ${ }^{76}$.

Cumpre ressaltar que muitos estados americanos ainda consideram as práticas homossexuais como crime.

O parlamento da Nova Zelândia reconheceu recentemente a união civil entre gays. O casamento homossexual, contudo, não foi admitido. Foram 65 votos a favor e 55 votos contrários ao projeto que disciplina as

\footnotetext{
${ }^{73}$ BRITO, Fernanda de Almeida. União afetiva entre homossexuais e seus aspectos jurídicos. São Paulo: LTr, 2000. p. 64.

${ }_{74}^{74}$ BRANDÃO, Débora Vanessa Caús. Op. cit. p. 59.

75 REDAÇÃO TERRA. Bush volta a atacar casamento homossexual. Disponível em $<$ www.midiaindependente.org/pt/bleu/2004/01/273310.shtml $>$. Acesso em 24 jan. 2005.

${ }^{76}$ ADITAL. União homossexual ganha reconhecimento. Disponível em<www.adital.org.br/site/noticia.asp?cod=11042\&lang=PT>. Acesso em 24 fev. 2005.
} 
parcerias homossexuais. A partir de abril desse ano os casais homossexuais têm suas relações formalmente reconhecidas, mas simplesmente como união homossexual e não como casamento, que permanece sendo um instituto exclusivo para a união entre um homem e uma mulher ${ }^{77}$.

A questão da união homossexual na França é baseada no princípio da igualdade, disposto no artigo primeiro da Declaração dos Direitos do Homem e do Cidadão, de 1789, e no princípio da proteção da vida privada.

Em 1999, foi publicada na França a Lei 99-944 e seus decretos regulamentares $\mathrm{n}^{\text {os }}$. 99-1.1.089, 1.090 e 1.091 , todos também do ano de 1999. Essa lei dispõe acerca do Pacto Civil de Solidariedade (PACS), que é um contrato entre duas pessoas maiores, de sexo diferente ou do mesmo sexo, que organiza a vida mútua.

O PACS é um contrato solene quando registrado, e com isso surtirá efeitos contra terceiros. Assim como no matrimônio, há no PACS impedimentos à sua celebração tais como: ascendentes e descendentes não podem celebrá-lo, tendo em vista a filiação; os colaterais até $3^{\circ}$ grau também não podem celebrá-lo. Há a previsão de uma sanção em caso de ser celebrado o PACS entre ascendente e descendente, qual seja, a nulidade. Os parentes por afinidade e pessoas menores de idade também estão impedidos de celebrar o $\mathrm{PACS}^{78}$.

Para que o PACS passe a produzir efeitos jurídicos é necessário que ele seja escrito em duas vias, constando da descrição a forma com que cada celebrante contribuirá para a vida em comum, assim como a previsão da divisão dos bens em caso de ruptura $^{79}$, devendo ser seguido um procedimento específico.

Através do PACS será reconhecido ao sobrevivente o direito a uma pensão em razão da morte de seu parceiro, assim como há, também, uma

\footnotetext{
${ }^{77}$ YAHOO NOTÍCIAS. Parlamento da Nova Zelândia reconhece união civil gay. Disponível em $<$ br.news.yahoo.com/041210/5/pvkh.html >. Acesso em 10 fev. 2005.

${ }^{78}$ BRANDÃO, Débora Vanessa Caús. Op. cit. p. 54.

${ }^{79}$ Ibid. p. 55.
} 
previsão de total cobertura médica ao parceiro descoberto em caso de morte de seu parceiro segurado ${ }^{80}$.

A França, no entanto, não reconhece o casamento homossexual, tendo a justiça francesa, a respeito desse tema, anulado, em julho de 2004, um casamento entre homossexuais. A procuradora da república, MarieHelene de la Landelle, argumentou que o casamento não foi celebrado de acordo com o Código Civil, tendo o tribunal aceitado esse argumento. O casamento celebrado pelo prefeito ecológico Noel Mamere foi considerado inválido e o prefeito foi afastado do cargo por um mês ${ }^{81}$.

No dia 21 de abril deste ano, os deputados espanhóis aprovaram, por 183 votos a 136 , o projeto de lei proposto pelo governo socialista ${ }^{82}$, fazendo com que a Espanha seja o terceiro país da Europa a reconhecer um casamento entre homossexuais, antecedido pela Bélgica e Holanda ${ }^{83}$. A lei conferirá ao casal homossexual o mesmo status dos casais heterossexuais casados, sendo garantido o direito à herança, à pensão e a possibilidade de adoção de filhos. O projeto ainda deve ser submetido ao senado, somente por uma mera formalidade.

A nova Lei aprovada desagradou a Igreja Católica espanhola que se pronunciou dizendo ser a "lei injusta e prejudicial ao bem comum" Partido Popular se opôs à lei, argumentando que os seus membros defendem direitos iguais e o reconhecimento de uma união civil entre homossexuais. Porém não defendem que esse tipo de união possa ser um casamento, exatamente igual ao dos heterossexuais ${ }^{85}$.

\footnotetext{
${ }^{80}$ BRANDÃO, Débora Vanessa Caús. Op. Cit.,p. 56.

${ }^{81}$ FOLHA ON LINE. Justiça anula primeiro casamento homossexual realizado na França. Disponível em <www1.folha.uol.com.br/folha/mundo/ult94u75082.shtml $>$. Acesso em 10 mar. 2005.

82 THOMAZ, Emma Ross. Espanha desafia Igreja e aprova casamento homossexual. Disponível em < http://br.news.yahoo.com/050421/5/tj9l.html>. Acessado em 25 de abri. 2005.

${ }^{83}$ FOLHA ON LINE. Deputados da Espanha aprovam o casamento entre gays. Disponível em $<$ www1.folha.uol.com.Br/folha/mundo/ult94u83061.shtml $>$. Acessado em 25 de abr. 2005. 84 Ibid.

${ }^{85}$ THOMAZ, Emma Ross. Espanha desafia Igreja e aprova casamento homossexual. Disponível em $<$ http://br.news.yahoo.com/050421/5/tj91.html>. Acessado em 25 de abri. 2005.
} 
Em países com uma tradição religiosa mais marcante, como a Arábia Saudita, os homossexuais são perseguidos e até mesmo condenados à morte. Em janeiro de 2002, na Arábia Saudita, foram executados três homens acusados de sodomia e condenados pelo tribunal religioso do fundamentalismo islâmico. O julgamento foi confirmado pelos tribunais superiores $^{86}$.

Como se pode perceber, poucos países atualmente reconhecem uma união entre pessoas do mesmo sexo. Somente Dinamarca, Groelândia, Hungria, Islândia, Noruega, Suécia, Holanda, França, Finlândia e Espanha regulamentaram essas uniões. Em outros países como Bélgica, Canadá, Estados Unidos e África do Sul, há o reconhecimento de um contrato de parceria civil, e não uma regulamentação da união homossexual, porém não em todo o território nacional, somente em alguns de seus Estados, províncias ou cidades..

A maior parte dos países não chegou a uma conclusão sobre o tema, permanecendo a discussão até hoje e certamente ainda continuará por um bom tempo.

\section{2}

\section{União homossexual no Direito Brasileiro.}

A questão da união homossexual no Brasil ainda não está pacificada. Há uma grande discussão acerca do tema e vários projetos de lei ainda não votados que dizem respeito a essas uniões.

A Constituição brasileira não reconhece, como antes dito, a união entre pessoas do mesmo sexo, ficando essas pessoas fora da proteção do

\footnotetext{
${ }^{86}$ ESTOU FELIZ ASSIM. Uma trajetória contra o preconceiro. Disponível em $<$ www.estoufelizassim.hpg.ig.com.br/cronologia6.html> . Acessado em 01 mar. 2005.
} 
Direito de Família. Apesar de não receberem proteção como entidades familiares, alguns direitos são reconhecidos aos homossexuais enquanto casais.

\subsection{1}

Efeitos patrimoniais decorrentes da dissolução inter vivos da união homossexual.

A união homossexual, conforme já comentado no item 3.2 do capítulo 3 do presente trabalho, não é reconhecida pelo Direito brasileiro, especialmente pelo Direito de Família Dessa forma, os efeitos patrimoniais decorrentes da dissolução dessas uniões não são previstos expressamente, diferentemente do que ocorre quando da dissolução do casamento ou da união estável, em que há a previsão de um regime de bens e normas regulamentando a partilha do patrimônio do casal segundo o tipo de regime escolhido por eles.

Quando um casal homossexual pleiteia no Judiciário a partilha de seu patrimônio, os tribunais, para não deixar o caso sem solução, resolvem o pleito através das normas de direito obrigacional, tendo em vista que não há qualquer previsão legal quanto à partilha do patrimônio do casal homossexual.

A súmula 380 do Supremo Tribunal Federal, que consagra a dissolução entre concubinos, passou a ser utilizada como solução para os casos de partilha de patrimônio do casal homossexual. A súmula autoriza a dissolução judicial quando há a possibilidade de se reconhecer uma sociedade de fato, partilhando-se os bens havidos pelo esforço comum. 
Os casais homossexuais, vivendo juntos, acabam por praticar atos da vida civil, fazendo com que não se possa deixar de apreciar esses atos quando da dissolução dessa sociedade. Sendo assim, o juiz ao reconhecer a contribuição para a formação do patrimônio comum, quando do término da sociedade, deverá proceder à partilha desse patrimônio.

A seguinte ementa ilustra essa posição que vem sendo adotada nos Tribunais de Justiça brasileiros em geral:

Direito Civil. Sociedade de Fato. Relação Homossexual. Possibilidade. O direito brasileiro não veda a sociedade de fato entre pessoas do mesmo sexo, sendo necessário, entretanto, a demonstração da existência da contribuição de cada um para formação do patrimônio comum. Revelia. As regras que regem a revelia determinam que sejam considerados verdadeiros os fatos alegados com a inicial. Porém, essa presunção não se verifica quando os próprios documentos trazidos pela parte autora contradizem sua afirmação. Improcedência mantida ${ }^{87}$.

O Superior Tribunal de Justiça, em julgamento de causa semelhante, reconheceu igualmente uma sociedade de fato entre um casal homossexual, determinando que fossem partilhados os seus bens.

Sociedade de fato. Homossexuais. Partilha do bem comum. O parceiro tem o direito de receber a metade do patrimônio adquirido pelo esforço comum, reconhecida a existência de sociedade de fato com os requisitos no artigo 1363 do Código Civil ${ }^{88}$.

Os casais homossexuais que buscam o Judiciário para resolverem a questão da divisão de seus bens, como dito acima, têm como solução o reconhecimento de uma sociedade de fato, e não uma união estável. Porém, o Tribunal do Rio Grande do Sul vem se mostrando tendente a reconhecer uma possível união estável homossexual, baseando-se na idéia de que nessas uniões, assim como na união estável entre heterossexuais, existe afeto, não podendo o judiciário ignorar essas realidades, buscando a aplicação da analogia e dos Princípios Gerais do Direito. A ementa da Apelação Cível n ${ }^{0} 70001388982$, julgada no dia 14 de março do ano de 2001

\footnotetext{
${ }^{87}$ TJRJ, Apelação Cível n. 2003.001.24718, Rel. Antonio César Siqueira, Rio de Janeiro, 11 nov. 2003.

${ }^{88}$ STJ, RESP 148897/MG, Rel. Min. Ruy Rosada de Aguiar, Brasília, 06 abr. 1998.
} 
pela sétima Câmara Cível do Tribunal de Justiça do Rio Grande do Sul, ilustra essa posição inovadora comentada:

União homossexual. Reconhecimento. Partilha do patrimônio. Meação paradigma. Não se permite mais o farisaísmo de desconhecer a existência de uniões entre pessoas do mesmo sexo e a produção de efeitos jurídicos derivados dessas relações homoafetivas. Embora permeadas de preconceito, são realidades que o judiciário não pode ignorar, mesmo em sua natural atividade retardatária. Nelas remanescem conseqüências semelhantes as que vigoram nas relações de afeto, buscando-se sempre a aplicação da analogia e dos Princípios Gerais do Direito, relevando sempre os Princípios Constitucionais da dignidade da pessoa humana e da igualdade. Desta forma, o patrimônio havido na constância do relacionamento deve ser partilhado como na união estável, paradigma supletivo onde se debruça a melhor hermenêutica. Apelação provida, em parte, por maioria, para assegurar a divisão do acervo entre os parceiros ${ }^{89}$.

O mesmo Tribunal atribuiu competência às Varas de Família para o julgamento das causas de dissolução da sociedade de fato homossexual, tendo em vista que essas sociedades, diferentes das outras sociedades de fato, são sociedades de afeto, não sendo possível qualquer tipo de discriminação, em especial quanto à opção sexual.

Relações homossexuais. Competência da Vara de Família para julgamento de separação em sociedade de fato. A Competência para o julgamento de separação de sociedade de fato de casais formados por pessoas do mesmo sexo, é das Varas de Família, conforme precedente desta Comarca, por não ser possível qualquer discriminação por se tratar de união entre homossexuais, pois certo que a Constituição Federal, consagrando o Princípio Democrático de Direito, proíbe discriminação de qualquer espécie, principalmente quanto à opção sexual, sendo incabível, assim, quanto à sociedade de fato homossexual. Conflito de Competência acolhido ${ }^{90}$.

Como visto, a questão da divisão patrimonial dos casais homossexuais, atualmente, pela maioria dos Tribunais do Brasil, é solucionada pelo reconhecimento de uma sociedade de fato, sendo partilhado o acervo comum resultante do esforço de ambos, porém há uma tendência, em especial por parte do Tribunal do Rio Grande do Sul, em estender os efeitos patrimoniais relativos às uniões estáveis, conferindo ao

\footnotetext{
${ }^{89}$ TJRS, Apelação Cível n. 70001388982, Rel. Ministro José Carlos Teixeira Giorgis, Rio Grande do Sul, 14 mar. 2001.

${ }^{90}$ TJRS, Conflito de Competência n. 70000992156, Rel. Ministro José Ataídes Siqueira Trindade, Rio Grande do Sul, 29 jun. 2000.
} 
casal homossexual os mesmos direitos conferidos ao casal heterossexual em união estável.

\subsection{2}

\section{Sucessão entre os parceiros homossexuais.}

O artigo 1829 do atual Código Civil, situado no capítulo referente à ordem de vocação hereditária, dispõe sobre a sucessão legítima, não reconhecendo nenhum direito ao homossexual quando da morte de seu companheiro. Com isso, os bens deixados pelo de cujus homossexual vão para os seus familiares.

Muitos homossexuais vivem vários anos longe de suas famílias, pois, ao anunciarem sua opção sexual, os familiares acabam por lhes negar apoio e muitas vezes acabam por expulsá-los de casa. Quando morrem sem deixar qualquer testamento, o seu patrimônio vai para os familiares que os rejeitaram, Assim, o parceiro do homossexual, que esteve sempre ao seu lado, quando não consegue obter parte do patrimônio pelo reconhecimento de uma sociedade de fato, fica sem qualquer amparo legal, totalmente desprotegido. Situação pior acontece quando o patrimônio do de cujus, por não possuir uma família, vai para o Estado pela declaração de vacância.

Atualmente, verifica-se em algumas decisões que os juizes, tentando integrar o Direito à realidade social, em razão das transformações ocorridas na sociedade, acabam por usar em sua fundamentação Princípios Gerais do Direito, utilizando-se igualmente de analogias ${ }^{91}$.

A Justiça do Rio Grande do Sul, com relação à sucessão hereditária, tem, em suas decisões, integrado o parceiro homossexual na ordem de

\footnotetext{
${ }^{91}$ RIBEIRO, Thaysa Halima Sauáia. Adoção e sucessão nas células familiares homossexuais: Equiparação à união estável. $\quad$ Disponível em $<$ http://www1.jus.com.br/doutrina/texto.asp?id=3790>. $\quad$ Acesso 02 fev. 2005.
} 
vocação hereditária. Foi também nesse Estado que, em sede recursal, visualizou-se a existência de uma entidade familiar decorrente de união homossexual, como já comentado no item 4.2.1. Nos Embargos Infringentes número 70003967676, julgado no dia 9 (nove) de maio de 2003 pelo Quarto Grupo de Câmaras Cíveis, foram conferidos direitos sucessórios ao parceiro homossexual sobrevivente, pois foi reconhecida a existência de uma união estável homoafetiva, com a aplicação da analogia, tendo sido publicada a seguinte ementa:

União estável homoafetiva. Direito sucessório. Analogia. Incontrovertida a convivência duradoura, pública e continua entre parceiros do mesmo sexo, impositivo que seja reconhecida a existência de uma união estável, assegurando ao companheiro sobrevivente a totalidade do acervo hereditário, afastada a declaração de vacância da herança. A omissão do constituinte e do legislador em reconhecer efeitos jurídicos as uniões homoafetivas impõe que a justiça colmate a lacuna legal fazendo uso da analogia. $\mathrm{O}$ elo afetivo que identifica as entidades familiares impõe seja feita analogia com a união estável, que se encontra devidamente regulamentada. Embargos Infringentes acolhidos, por maioria ${ }^{92}$.

A Oitava Câmara Cível do mesmo Tribunal julgou a apelação cível número 70006844153 de maneira semelhante, tendo sido publicada a seguinte ementa:

União homoafetiva. Possibilidade jurídica. Observância dos princípios da igualdade e dignidade da pessoa humana. Pela dissolução da união havida, caberá a cada convivente a meação dos bens onerosamente amealhados durante a convivência. Falecendo a companheira sem deixar ascendentes ou descendentes caberá à sobrevivente a totalidade da herança. Aplicação analógica das leis $\mathrm{n}^{\mathrm{o}}$ $8.871 / 94$ e 9.278/96. Por maioria, negaram provimento, vencido o revisor $^{93}$.

Com isso, diante da omissão legal, é possível que os magistrados comecem a aplicar analogicamente a legislação que regula a sucessão nas uniões estáveis às uniões entre pessoas do mesmo sexo.

\footnotetext{
${ }^{92}$ TJRS, Embargos Infringentes n. 70003967676, Rel. Maria Berenice Dias, Rio Grande do Sul, 05 mai. 2003.

${ }^{93}$ TJRS, Apelação cível n. 70006844153, Rel. Catarina Rita Krieger Martins, Rio Grande do Sul, 18 dez. 2003.
} 


\subsection{3}

\section{Adoção por homossexuais.}

Outra questão importante envolvendo homossexuais diz respeito à adoção de crianças.

Em vários países em que são reconhecidas uniões homossexuais, a questão da adoção não se encontra resolvida. Há o reconhecimento dessas uniões, porém não há a previsão de o casal poder adotar uma criança. Aqui no Brasil, como a união homossexual ainda não é reconhecida pelo Direito de Família, os casais homossexuais não podem, por óbvio, adotar em conjunto uma criança. Apesar disso, uma pessoa homossexual pode ter deferida em seu favor uma adoção.

O artigo 42 do Estatuto da Criança e do Adolescente prescreve que "podem adotar os maiores de 21 anos, independentemente do estado civil", não fazendo menção à orientação sexual da pessoa. Também o artigo 43 do mesmo Estatuto diz que "a adoção será deferida quando apresentar reais vantagens para o adotando e fundar-se em motivos legitimos". Sendo assim, os principais requisitos para se adotar uma criança são ter mais de 21 anos e conduta social adequada, independente do estado civil. Seguindo essa linha de raciocínio, não haveria qualquer impedimento para uma pessoa homossexual adotar uma criança, porém a realidade não se mostra nesse sentido. Muitas são as resistências em aceitar a adoção por um homossexual.

Existem muitos motivos suscitados que levam à impossibilidade de adoção de uma criança por um homossexual, sendo o maior deles a questão do desenvolvimento sadio do menor, pois há a preocupação de que a criança, sendo criada por um homossexual, possa ter uma tendência para esse tipo de comportamento. Outra questão que se levanta é a possibilidade 
de o filho adotado ser alvo de repúdio no meio que freqüenta ${ }^{94}$. Quando o homossexual adotante vive em um relacionamento estável com uma pessoa do mesmo sexo, essas críticas são ainda maiores.

Essas questões foram alvo de estudos nos Estados Unidos, onde pesquisadores observando, o comportamento de famílias homossexuais, chegaram à conclusão de que as crianças criadas por pais homossexuais podem ser tão socialmente ajustadas quanto as crianças educadas por heterossexuais ${ }^{95}$.

Atualmente, quando uma pessoa homossexual consegue adotar uma criança, os eventuais direitos do adotado só poderão ser buscados com relação ao adotante. Portanto, se o adotante viver com um parceiro homossexual, essa criança não terá qualquer direito sucessório, nem mesmo direito de pleitear alimentos em relação à pessoa que ajudou a criá-lo.

Para que seja realizada uma adoção, o que deve ser levado em conta é o interesse da criança. A desembargadora Maria Berenice Dias argumenta que, sob o princípio da legalidade, sem limitação legal não se pode negar o direito da criança e do adolescente à adoção, que lhes irá assegurar um lar ${ }^{96}$. Sendo assim, se uma pessoa que se diga homossexual tiver condições, e a sua situação for mais vantajosa para a criança, não há motivos para a negação do seu pedido de adoção. Mesmo sabendo-se que a pessoa interessada na adoção convive com um parceiro do mesmo sexo, em havendo afeto, lealdade, fidelidade, não se pode afirmar que, somente por ser a pessoa homossexual, não haverá vantagens para o menor. $\mathrm{O}$ juiz da $1^{\mathrm{a}}$ Vara da Infância e da Adolescência do Rio de Janeiro, Siro Darlan, disse, em entrevista à revista Isto É, em setembro de 1998, que “o que está em

94 DIAS, Maria Berenice. Adoção Homoafetiva. Disponível em $<$ www.desobedeca.com.br/noticias/adocaohomoafetiva.htm>. Acesso em 28 mai. 2005.

95 BRANCATELLI, Rodrigo; NOGUEIRA, Fernanda. Casais gays podem adotar crianças? Disponível em < http:// noticias.aol.com.Br/ping_fogo/2004/0017.adp>. Acesso em 28 mai. 2005.

${ }^{96}$ DIAS, Maria Berenice. Adoção Homoafetiva. Disponível em $<$ www.desobedeca.com.br/noticias/adocaohomoafetiva.htm>. Acesso em 28 mai. 2005. 
jogo é se o candidato tem disponibilidade e equilíbrio emocional além de recursos financeiros", disse também que "os valores da sociedade mudam. Buscamos o melhor para as crianças independentemente da opção sexual dos pais" 97 .

A Promotora de Justiça do Juizado Regional da Infância e da Juventude da Comarca de Passo Fundo, em processo de habilitação por uma mulher homossexual, elaborou um parecer opinando pelo deferimento da habilitação. Argumentou em seu parecer que a requerente forneceu subsídios concretos favoráveis a sua personalidade e conduta, além de trabalhar diretamente com crianças em uma escolinha de artes, sendo, por isso, capaz de criar bem e amar uma criança. Argumentou também que a requerente era estéril, e por isso, assim como para as demais mulheres que se encontrem na mesma situação, a possibilidade da adoção não poderia lhe ser negada tal possibilidade ${ }^{98}$.

Essa questão da adoção de menores por pessoas homossexuais foi retratada em uma novela da emissora Globo, nesse ano de 2005, Senhora do Destino, onde uma mulher homossexual pôde adotar um menor, o qual havia encontrado em um lixo, próximo ao hospital em que trabalhava. $\mathrm{Na}$ novela, foi demonstrado que essa personagem conseguiu adotar a criança por já ter uma ligação de afeto com a mesma e a sua condição de homossexual não atrapalharia em nada a criação do menor.

Por fim, partilhando do posicionamento que leva em consideração o melhor interesse da criança, é preciso que os juízes das Varas da Infância e da Adolescência atentem para o caso concreto e para os ditames legais,

\footnotetext{
${ }^{97}$ ISTO É. Encontro antecipado no Rio: juiz permite adoção por mães e pais solteiros e reduz a espera das crianças por um lar. Disponível em $<$ http://www.terra.com.br/istoe/comport/151020.htm>. Acesso em 28 mai. 2005.

${ }^{98}$ CIRNE, Ana Cristina Ferrareze. Habilitação para adoção: Parecer do Ministério Público. Disponível 
levando em consideração o ambiente em que a criança será inserida e as reais condições do adotante, sem se preocupar com opção sexual do mesmo, mas somente com o bem estar da criança.

\subsection{4}

\section{Legislação previdenciária e a união homossexual.}

O Direito previdenciário sempre se mostrou inovador. Um exemplo disso foi o reconhecimento de direitos à concubina mesmo antes da união estável ser reconhecida pelo direito e merecedora de regulamentação ${ }^{99}$. Com relação às uniões homossexuais e o reconhecimento de direitos ao companheiro, o Direito Previdenciário inovou mais uma vez.

A legislação que trata da previdência social não diz expressamente que os companheiros beneficiários sejam de sexo diferente, não vedando que tenham o mesmo sexo. Como o benefício previdenciário é um direito decorrente do trabalho remunerado e do pagamento de contribuições previdenciárias, garantido ao segurado e seus dependentes nos termos do artigo 201 da Constituição Federal e do artigo 215 da Lei no. 8112/90, não deve haver nenhum tipo de discriminação, devendo ser respeitados os princípios constitucionais da liberdade, isonomia e dignidade da pessoa humana.

Em razão de uma ordem judicial proferida pela juíza da $3^{\mathrm{a}}$ Vara Previdenciária de Porto Alegre, o Instituto Nacional do Seguro Social expediu a Instrução Normativa n. 25, de 07.06.2000, regulando os procedimentos a serem adotados para a concessão de benefícios previdenciários ao companheiro ou companheira homossexual. A decisão que motivou a expedição da referida Instrução Normativa teve origem na

\footnotetext{
${ }^{99}$ BRANDÃO, Débora Vanessa Caús. Op. cit., p. 106.
} 
Ação Civil Pública n. 2000.71.00.009347-0, intentada pelo Ministério Público Federal contra o Instituto Nacional do Seguro Nacional e determinou que o INSS fizesse a inscrição do companheiro de segurado homossexual como seu dependente principal, garantindo a percepção de auxílio-reclusão e pensão por morte do beneficiário.

Em maio de 2001, o INSS expediu nova Instrução Normativa estendendo os benefícios de pensão por morte e auxílio-reclusão a todos os companheiros de homossexuais mortos ou presos. A Instrução Normativa n. 50/2001, em seu artigo $4^{\circ}$, diz que os benefícios previdenciários devem ser concedidos independentemente da data de ocorrência do óbito ou encarceramento do segurado. A nova Instrução Normativa foi expedida em razão de uma determinação judicial, pois a autarquia estava limitando a concessão dos benefícios aos óbitos e prisões posteriores à Instrução Normativa n. $25 / 2000^{100}$, ficando os companheiros(as) de homossexuais mortos ou presos antes da referida Instrução Normativa ao desabrigo da mesma.

Vários julgados no Brasil, envolvendo direitos dos homossexuais, se mostraram a favor deles, principalmente contra o INSS, no caso de concessão de pensão por morte ao companheiro(a) homossexual.

\subsection{5}

\section{Legislações Estaduais e os homossexuais.}

Vários Estados do Brasil publicaram leis proibindo a discriminação contra homossexuais, assim como leis que reconhecem alguns direitos previdenciários aos companheiros de funcionários públicos homossexuais.

\footnotetext{
${ }^{100}$ BRANDÃO, Débora Vanessa, Caús. Op. cit., p. 108.
} 
No Estado do Rio de Janeiro, em 2000, foi aprovada a lei n. 3406 que condena a discriminação e humilhação de pessoas por sua orientação sexual, prevendo penalidades, como multa e interdição de estabelecimentos públicos e privados, tais como motéis e restaurantes, que derem tratamento diferenciado a homossexuais ${ }^{101}$.

Em Minas Gerais, foi sancionada, no ano de 2002, pelo então Governador Itamar Franco, a lei 14170, coibindo a discriminação contra pessoas em virtude de sua orientação sexual, estabelecendo ainda algumas penalidades para as pessoas jurídicas de direito público e privado, tais como advertência, suspensão de funcionamento de estabelecimento, inabilitação para concessão de isenção, remissão, anistia ou quaisquer outros benefícios de natureza tributária, multas que podem chegar a $\mathrm{R} \$ 50.000,00$, dentre outras. Com isso os homossexuais passaram a poder livremente manifestar seu afeto um pelo outro em espaço público sem que isso fosse considerado atentado violento ao pudor. O Estado de São Paulo, seguindo a mesma linha, aprovou um projeto, pela Câmara de São José do Rio Preto, dando origem à Lei 181/01, que proíbe a discriminação por orientação sexual. Em Londrina, no Paraná, a Câmara dos Vereadores também aprovou a Lei nº $117 / 02$, passando a proibir que qualquer estabelecimento discrimine os homossexuais, estabelecendo uma multa pelo descumprimento.

No mesmo ano de 2002, o Município do Recife foi o primeiro do Brasil a incluir, no benefício da concessão de pensão em caso de morte, os companheiros e filhos dos servidores públicos homossexuais. Os servidores poderão deixar uma pensão, em caso de sua morte, para os seus filhos e companheiros, sejam eles heterossexuais ou homossexuais. A regulamentação do decreto do então prefeito João Paulo foi publicada no Diário Oficial, no dia 16 de março de 2002.

\footnotetext{
${ }^{101}$ MANDATO. Quinze anos em defesa dos homossexuais. Disponível em <www.minc.com.br>. Acessado em 30 mar. 2005.
} 
Os servidores estaduais homossexuais do Rio de Janeiro ganharam o direito de poder garantir os direitos previdenciários aos seus companheiros. A Lei Estadual n ${ }^{\circ} .3 .786$ de 2002 entrou em vigor, tendo a Assembléia Legislativa derrubado o veto do então Governador Anthony Garotinho. O projeto de lei foi de autoria do deputado Carlos Minc e do atual senador Sérgio Cabral Filho. Porém, alguns dias depois, o desembargador José Carlos Schmidt Ribeiro, do Tribunal de Justiça do Rio de Janeiro, concedeu uma liminar tornando sem efeito a referida Lei Estadual. O deputado Carlos Minc anunciou que interporia recurso pedindo a cassação da liminar.

Atualmente a lei $\mathrm{n}^{\circ}$. 4320/04, aprovada pela Alerj, continua garantindo os direitos aos companheiros e companheiras de funcionários públicos homossexuais, estabelecidos pela lei de Carlos Minc e Sérgio Cabral. A governadora Rosinha, tentando derrubar a Lei 3786/02, anteriormente comentada, enviou à Alerj a mensagem 31/2003, que trazia diversas modificações à legislação previdenciária do Estado do Rio de Janeiro. No que diz respeito aos homossexuais, a mensagem da governadora suprimia o $\S 7^{\circ}$ do Artigo 29, que equiparava à condição de companheira ou companheiro os parceiros do mesmo sexo que mantivessem relacionamento de união estável. A Alerj, porém, modificou o projeto de lei originado pela mensagem da governadora $^{102}$, mantendo a extensão dos benefícios previdenciários dos servidores estaduais a parceiros do mesmo sexo.

No Rio Grande do Sul existe uma ONG chamada SOMOS, comunicação, saúde e sexualidade, que em outubro de 2004, lançou o projeto Libertas. Esse projeto, financiado pelo Ministério da Saúde e pela UNESCO, visa oferecer assistência jurídica gratuita, com uma equipe própria de advogados, a homossexuais vítimas de violência ou

\footnotetext{
${ }^{102}$ MANDATO. Vitória histórica pelos direitos previdenciários de parceiros do mesmo sexo de servidores públicos. Disponível em <www.minc.com.br/mandato/cidadani/lei378.htm>. Acesso em 15 de mar. 2005.
} 
discriminação por orientação sexual ou por serem portadores do vírus HIV. A divulgação do projeto foi feita por atores que interpretaram nas ruas da cidade, criando uma situação de discriminação ${ }^{103}$.

Como visto, a questão do homossexual no Brasil vem sendo discutida e reconhecida em vários Estados. Se o Brasil continuar a caminhar a passos largos nesse sentido, não tardará para que seja possível o reconhecimento legal da união homossexual e sua inclusão no Direito de Família.

Com relação a esse tema, Silvio de Salvo Venosa fez um comentário muito pertinente, que merece ser citado:

Destarte, enquanto não houver aceitação social majoritária das uniões homoafetivas em nosso País, que se traduza em uma possibilidade legislativa, as uniões de pessoas do mesmo sexo devem gerar apenas reflexos patrimoniais relativos às sociedades de fato. No entanto, crescem os julgados e os movimentos no sentido de que esses direitos ganhem maior amplitude. Será uma questão de tempo mais ou menos longo para a lei admitir direitos mais ou menos amplos às relações afetivas e duradouras a pessoas do mesmo $\operatorname{sexo}^{104}$.

\subsection{6}

O Projeto de Lei 1.151/95 e seu substitutivo.

O Projeto de Lei 1.151/95 visa disciplinar a união civil entre pessoas do mesmo sexo. Não se trata de um casamento, mas sim de uma união civil,

\footnotetext{
${ }^{103}$ ADITAL. União homossexual ganha reconhecimento. Disponível em $<$ http://www.adital.org.br/site/not icias/14271.asp?lang=PT\&cod=14271>. Acesso em 23 jan. 2005.

${ }^{104}$ VENOSA, Silvio de Salvo. Op. cit., p. 482.
} 
já existente em alguns países do mundo. $\mathrm{O}$ referido projeto foi apreciado por uma comissão especial instalada na Câmara do Deputados.

O texto do Projeto é composto de 18 artigos que disciplinam o direito à sucessão, a benefícios previdenciários, ao seguro saúde conjunto, à inscrição como dependente no imposto de renda e o direito à aquisição da nacionalidade brasileira no caso de estrangeiros.

Esse Projeto é a primeira tentativa de regulamentação da união entre pessoas do mesmo sexo.

O casal homossexual que quiser ter reconhecida legalmente a sua união civil deverá, conforme o artigo $2^{\circ}$ do projeto, registrá-la em livro próprio, nos Cartórios de Registro de Pessoas Naturais. As pessoas interessadas deverão ter capacidade civil plena, como também deverão ser solteiras, viúvas ou divorciadas, não podendo contrair casamento ou outra união civil na vigência do contrato de união civil.

Essas uniões civis serão averbadas nos assentos de nascimento e casamento das partes.

O contrato será livremente pactuado e deverá versar sobre disposições patrimoniais, deveres e obrigações mútuas. Sob o aspecto jurídico existem algumas diferenças entre o casamento e o contrato de parceria. No casamento, os nubentes aderem às cláusulas existentes no Código Civil e somente poderão escolher o regime de bens adotando as regras do regime escolhido. No caso da união civil, os contratantes irão pactuar livremente sobre a disposição patrimonial, deveres e obrigações mútuas.

O contrato de união civil será desfeito mediante desistência das partes ou por morte de um dos contratantes. 
No texto do Projeto não há referência sobre qual seria o foro competente para julgar os processos oriundos de uma união civil entre pessoas do mesmo sexo, ficando a dúvida se a competência seria da Vara Cível ou da Vara de Família. Essa é uma questão que precisará ser discutida quando o Projeto for colocado em votação.

Prestando um depoimento junto à comissão apreciadora do projeto, o jurista paranaense Edson Fachin sugeriu a substituição do termo "união" pelo termo "parceria". O relator do projeto, Roberto Jefferson, aceitou a sugestão, entendendo-a correta, e fez a substituição, no final de 1996. O substitutivo adotado pela comissão do projeto de Lei da ex-deputada Marta Suplicy acrescentou alguns incisos e parágrafos aos artigos do projeto originário. Foi acrescentado ao artigo $3^{\circ}$ um segundo parágrafo que veda quaisquer disposições sobre adoção, tutela ou guarda de crianças ou adolescentes em conjunto, assim como também ficou estabelecido que a extinção da parceria registrada poderá ser feita de forma consensual com posterior homologação pelo juiz, incluindo um terceiro inciso ao artigo $4^{\circ}$. Uma outra alteração feita pelo substitutivo diz respeito à proibição de parceria civil com mais de uma pessoa, constante do artigo $8^{\circ}$. Esse artigo foi reformulado no substitutivo, que dispõe que o contrato celebrado por uma pessoa que já esteja vivendo uma parceria civil registrada será nulo de pleno direito e ainda implicará no cometimento de crime de falsidade ideológica.

Várias são as críticas relativas a esse projeto. A principal delas diz respeito ao artigo $2^{\circ}$, que autoriza a parceria civil somente entre pessoas que sejam solteiras, viúvas ou divorciadas, impedindo que se altere o estado civil durante sua vigência, vedando que essas pessoas contraiam casamento. Maria Berenice Dias diz que, ao impedir que pessoas que estejam vivendo esse tipo de parceria civil registrada se casem, estaria se criando um novo 
impedimento para o casamento não elencado no art. 183 do Código Civil ${ }^{105}$. Estaria se criando, perigosamente, um novo estado civil, que não pode ser alterado sem a extinção do contrato de parceria civil registrada ${ }^{106}$. Há o reconhecimento de que o projeto seja de alta relevância, porém sem que seja preciso criar um novo estado civil, ficando somente a possibilidade de valer contra terceiros ${ }^{107}$.

Outra questão levantada diz respeito ao artigo $9^{\circ}$ do substitutivo, artigo 10 do projeto originário, que protege o bem imóvel próprio e comum dos contratantes de parceria civil registrada, declarando-o impenhorável, nos termos e condições regulados pela Lei $8.009 / 90^{108}$. Esta lei trata do bem de família, que somente poderá ser assim considerado no âmbito desta. Com isso, como o projeto não tem o intuito de reconhecer a constituição de uma família, se este artigo vingar, poderá esse dispositivo ser considerado uma exceção ao termo bem de família, como sendo próprio de uma família reconhecida pelo ordenamento jurídico.

Apesar de todas as críticas feitas, deve-se reconhecer que o projeto é uma tentativa de se regulamentar uma situação fática que há muito tempo existe entre nós. A semelhança entre um casamento ou até mesmo a uma união estável é esperada, uma vez que as uniões homossexuais ligam duas pessoas, apesar de terem o mesmo sexo, por afeto. Qualquer projeto que venha a versar sobre esse tema deverá se preocupar com a adoção de dispositivos que não levem a uma possível inconstitucionalidade, tendo em vista que a nossa Constituição Federal não reconhece a união entre pessoas do mesmo sexo como sendo um instituto do Direito de Família. Sobre a

\footnotetext{
${ }^{105}$ DIAS, Maria Berenice. "União homossexual: aspectos sócias e jurídicos". In: ANAIS DO II CONGRESSO BRASILEIRO DE DIREITO DE FAMÍLIA. A família na travessia do milênio. Belo Horizonte: 2000, p. 165.

${ }^{106}$ AZEVEDO, Álvaro Villaço. "União entre pessoas do mesmo sexo". In: ANAIS DO II CONGRESSO BRASILEIRO DE DIREITO DE FAMÍLIA. Op. cit., p. 152.

${ }^{107}$ Ibid. p. 153.

${ }^{108}$ Ibid. p. 157.
} 
importância do projeto, Maria Berenice Dias se manifestou da seguinte forma:

O inquestionável é que o projeto marca o início da saída da marginalidade dos vínculos afetivos homossexuais, deixando de ser excluídos para ser incluídos no laço social, obtendo o reconhecimento pelo Estado ${ }^{109}$.

O referido Projeto de Lei e o seu substitutivo são datados de 1995 e 1996, respectivamente, porém até os dias de hoje não chegou a ser votado no plenário da Câmara, ficando engavetado por vários motivos sendo o principal deles a forte pressão da Igreja Católica e dos evangélicos.

No dia 16 de março deste ano, 2005, o presidente da Câmara, Severino Cavalcanti (PP-PE), recebeu, em seu gabinete, gays, lésbicas, bissexuais, travestis e transgêneros. Eles conseguiram fazer com que o referido Deputado desengavetasse e prometesse colocar em votação o projeto da ex-deputada Marta Suplicy, e outro da deputada Iara Bernardi (PT-SP), que torna crime a discriminação motivada pela orientação sexual $^{110}$.

O presidente da Câmara disse que irá discursar contra os projetos, mas prometeu agir como um magistrado. Disse ainda:

"Vou sair da presidência e ir para a tribuna combater o que não acredito, mas o direito de ser votado eu vou respeitar... Se o Brasil tem democracia, vocês vão participar do processo" ${ }^{\text {"111 }}$.

Agora é esperar para ver.

109 AZEVEDO, Álvaro Villaço. "União entre pessoas do mesmo sexo". In: ANAIS DO II CONGRESSO BRASILEIRO DE DIREITO DE FAMÍLIA. Op. cit p. 165.

${ }^{110}$ LIMA, Maria. O novo queridinho dos homossexuais. O Globo, Rio de Janeiro, p. 4, 17 mar. 2005

${ }^{111}$ Ibid. 


\section{5.}

\section{Conclusão}

$\mathrm{O}$ direito, como ensina Miguel Reale ${ }^{112}$, corresponde à exigência essencial e indeclinável de uma convivência ordenada, pois nenhuma sociedade poderia subsistir sem o mínimo de ordem, assim sendo o direito seria um fato social que somente pode existir onde existe sociedade. Sendo o direito um instrumento usado para regrar a vida em sociedade, ele deve estar atendo às transformações que ocorrem para que possa, com isso, regulamentar as novas situações que surgirão, pois as sociedades se transformam a todo o momento.

O presente trabalho analisou a evolução do conceito de família, demonstrando que a mentalidade das sociedades com relação às formas de família existentes se modificou substancialmente, o que antes somente era possível através do casamento, hoje em dia também é possível através do reconhecimento de uma união estável e até mesmo sem precisar existir qualquer união, bastando apenas um dos pais e seus descendentes.

A Constituição Federal e o Código Civil, no tocante ao Direito de Família, ao exigirem como pressuposto de validade para o casamento e para a união estável a diversidade de sexos, acabou por excluirem expressamente as uniões homossexuais. Devido à existência desse pressuposto fático, esse tipo de união, não poderá ser equiparada ao casamento, nem mesmo à união estável.

O Direito brasileiro, por não reconhecer a união homossexual, acaba por levar os seus operadores a buscar outras soluções para os problemas que surgem ligados a esse tipo de união, uma vez que o ordenamento jurídico,

${ }^{112}$ REALE, Miguel. Lições preliminares de Direito. 25 . ed.. São Paulo: Saraiva, 2000. p. 2. 
especificamente no artigo $4^{\circ}$ da Lei de Introdução ao Código Civil, autoriza o juiz a decidir o caso de acordo com a analogia, os costumes e os princípios gerais de direito. Alguns doutrinadores, a exemplo de Miguel Reale, julgam ser somente possível o reconhecimento de uma união homossexual como entidade familiar através de uma Emenda à Constituição, porém, conforme demonstrado através de jurisprudências no capítulo quarto do presente trabalho monográfico, alguns juizes, fundamentando-se em princípios constitucionais, como o da igualdade, acabam por conferir direitos ao casal homossexual iguais aos que são conferidos ao casal heterossexual.

Uma solução encontrada, e mais comumente usada foi $o$ reconhecimento de uma sociedade de fato, o que deu uma certa garantia aos casais homossexuais em relação ao patrimônio comum, situando essas relações no plano do direito obrigacional, porém não garantiu o reconhecimento legal de uma união de afeto, de comunhão de vida e de interesses, deixando-os totalmente desamparados nesse sentido. As relações livres, hoje consideradas uniões estáveis, até mais da metade do século passado, não eram reconhecidas pelo Direito de Família, ficando sob a proteção do direito obrigacional, igualmente ao que hoje ocorre com relação às uniões entre homossexuais.

Como se pode perceber, a união estável, que até o final do século passado não era regulamentada pelo direito, passa a merecer uma proteção constitucional. Antes da Magna Carta de 1988, as demais Constituições somente reconheciam o casamento família, porém o Direito tendo que se adaptar às novas mudanças na vida da sociedade, acabou por reconhecer a união estável com a publicação de duas leis, datadas de 1994 e 1996, que regularam esse tipo de união.

Há, com isso, a confirmação de que o direito deve acompanhar as mudanças ocorridas na sociedade. Se esta aceita e se utiliza de outra forma de união que não o casamento, não há motivo para o direito se manter inerte 
diante de tal fato. Outros exemplos podem ser usados para demonstrar que o direito acompanha as transformações sociais, como é o caso do extinto crime de adultério, abolido do nosso ordenamento jurídico. Muitas questões que antes ficavam à margem do direito foram incluídas no ordenamento, pois os fatos sociais são fontes criadoras do Direito, permitindo a elaboração de normas para a regulamentação de fatos novos e práticas usadas pela sociedade.

A união homossexual é um fato social que esteve presente em toda a história da humanidade, porém foi sempre tratada à margem do direito por preconceito da sociedade. A homossexualidade chegou a ser considerada uma doença pela medicina, porém, até os dias de hoje, não se chegou a uma conclusão a esse respeito. Hoje em dia a homossexualidade é vista como um modo de ser da pessoa, dessa forma, alteração genética ou não, os homossexuais não podem ser discriminados pela sua condição, uma vez que a própria Constituição Federal proíbe expressamente qualquer tipo de discriminação.

Há atualmente uma grande tendência mundial em reconhecer as uniões homossexuais, somente em países onde a religião tem maior influência sobre a vida da sociedade em geral que existe uma maior resistência. A mentalidade das sociedades está se abrindo para um fato que existe desde muito tempo, aprendendo a respeitar as diferenças de uma forma mais liberal. Muitos países já ultrapassaram a barreira do preconceito e aceitaram a união entre pessoas do mesmo sexo, o que possibilitou o reconhecimento dessas uniões pelo Ordenamento Jurídico desses países.

No Brasil, a questão da parceria homossexual caminha para um reconhecimento por parte do Direito. Muitos tribunais, em especial os da região Sul, adotaram uma postura que possibilita o reconhecimento dessas parcerias como entidades familiares, mostrando através de diversos julgados que a união homossexual não diverge muito da união estável heterossexual. Há também benefícios previdenciários como a pensão por 
morte e o auxílio-reclusão concedidos ao parceiro homossexual, reconhecendo, portanto, a existência do afeto e do desejo de assistência mútua presente na relação desses casais.

A conclusão que pode ser tirada da análise dos fatos e dados recolhidos na presente monografia faz com que o reconhecimento das uniões entre pessoas do mesmo sexo, como entidade familiar merecedora do abrigo do Direito de Família, seja uma questão mais social e política do que jurídica O Direito possui ferramentas para incluir essas uniões, até então excluídas, ressaltando que a própria Constituição Federal traz em seu texto o princípio da igualdade, não só formal como também material, abrindo a possibilidade e a necessidade de entrada no ordenamento jurídico de uma lei que regule as parcerias homossexuais, bastando, para isso, conforme entendimento de alguns, uma Emenda Constitucional. Por motivos políticos, sociais, e até mesmo culturais, os homossexuais, enquanto casal, não têm direitos reconhecidos. 


\section{6.}

\section{Bibliografia.}

ADITAL. União Homossexual Ganha reconhecimento. Disponível em $<$ www.adital.org.br/site/noticia.asp?cod $=11042 \&$ lang=pt $>$. Acesso em 23 jan. 2005.

ALVES, Clêuser Lemos. Adoção e guarda de crianças por gays e lésbicas. Adoção: pessoas homossexuais podem adotar crianças. Disponível em $<$ www.umoutroolhar.com.br/direitos.htm>. Acesso em 28 de abr. 2005.

AZEVEDO, Álvaro Villaça. União entre pessoas do mesmo sexo. Disponível em <www.gontijo-familia.adv.br>. Acesso em 17 fev. 2005. . "União entre pessoas do mesmo sexo". In: ANAIS DO II CONGRESSO BRASILEIRO DE DIREITO DE FAMÍLIA. A família $n a$ travessia do milênio. Belo Horizonte: 2000, 578 p.

BRANCATELLI, Rodrigo; NOGUEIRA, Fernanda. Casais gays podem adotar crianças. Disponível em $<$ http://noticia.aol.com.br/ping_fogo/2004/0017.adp>. Acesso em 28 de abr. 2005.

BRANDÃO, Débora Vanessa Caús. Parcerias homossexuais: Aspectos jurídicos. São Paulo: Revista dos Tribunais, 2002. 149 p.

BRITO, Fernanda de Almeida. União afetiva entre homossexuais e seus aspectos jurídicos. São Paulo: LTR, 2000. 120 p.

CABEZÓN, Ricardo Moraes. Novo Código Civil: União homossexual caracteriza união estável?. Disponível em $<$ www.gendercare.com/br_rg52.html $>$. Acesso em 23 de jan. 2005.

CIOTOLA, Kátia Regina da Costa S.. O concubinato e as inovações introduzidas pelas Leis 8.971/94 e 9278/96. $3^{\mathrm{a}}$ ed. Rio de Janeiro: Lumem Júris, 1999. 121p.

CONGREGAÇÃO PARA DOUTRINA DA FÉ. Considerações sobre as propostas de reconhecimento legal das uniões entre homossexuais. 
Disponível em <http://geocities.com.br/amigosdafamiliabr/igreja.htm>. Acesso em 25 de abr. 2005.

CORREIA, Jadson Dias. Disponível em $<$ www.midiaindependente.org/em/red/2002/02/18021.shtml $>$. Acesso em 24 jan. 2005.

DIAS, Maria Berenice. "União homossexual: aspectos sócias e jurídicos". In: ANAIS DO II CONGRESSO BRASILEIRO DE DIREITO DE FAMÍLIA. A família na travessia do milênio. Belo Horizonte: 2000, 578 p.

Adoção Homoafetiva. Disponível em $<$ www.desobedica.com.br/noticias/adocaohomoafetiva.htm>. Acesso em 28 de abr. 2005.

DIAS, Maria Berenice; PEREIRA, Rodrigo da Cunha. Direito de Família e o novo Código Civil. $2^{\mathrm{a}}$.ed. Belo Horizonte: Del Rey, 2002. 295 p.

DINIZ, Maria Helena. Curso de Cireito Civil. 20ª ed.. São Paulo: Saraiva, 2003. $324 \mathrm{p}$.

DROPA, Romualdo Flávio. Direitos fundamentais, homossexualidade e uniões homoafetivas. Disponível em $<$ www.advogado.adv.br/artigos/2003/romualdoflaviodropa/direitoshomoafe tivos.htm>. Acesso em 24 jan. 2005.

ESTOU FELIZ ASSIM. Uma trajetória contra o preconceito. Disponível em <www.estoufelizassim.hpg.ig.com.br/cronologia.html > Acesso em 01 de mar. 2005.

FOLHA ONLINE. Justiça anula $I^{o}$ casamento homossexual na França. Disponível em <www1.folha.uol.com.br/folha/mundo/uit94u75082.shtml>. Acesso em 10 de mar. 2005.

FRANCE PRESSE. Deputados da Espanha aprovam o casamento entre gays. Disponível em $<$ www1.folha.uol.com.br/folha/mundo/ult94u83061.shtml $>$. Acesso em 25 de abr. 2005.

KUMPLE, Vitor. Breves reflexões sobre o homossexualismo. Disponível em <www.damasio.com.br/novo/html/frame_artigos.htm>. Acesso em 14 fev. 2005.

LIMA, Maria. O novo queridinho dos homossexuais. $O$ Globo, Rio de Janeiro, p. 4, 17 mar. 2005.

MANDATO. Vitória histórica pelos direitos previdenciários de parceiros do mesmo sexo de servidores público. Disponível em 
$<$ www,minc.com.br/mandato/cidadania/lei378.htm $>$. Acesso em 15 de abr. 2005 .

MARTINS, Rodrigo Monteiro. Legalização da união estável entre homossexuais. Disponível em $<$ www.drmaycon.hpg.ig.com.br/doutrina/direito_civil/legalizacao-da-uniaoestavel-homossexual.htm>. Acesso em 02 fev. 2005.

MONTEIRO, Washington de Barros. Curso de Direito Civil. $37^{\text {a }}$.ed. Rio de Janeiro: Saraiva, 2004. 359 p.

O GLOBO. Homossexuais se reúnem hoje com Severino. Disponível em $<$ www.oglobo.com>. Acesso em 16 mar. 2005.

PEIXINHO, Manoel Messias. A interpretação da Constituição e os principios fundamentais. Elemento para uma hermenêtica constitucional renovada. $2^{\mathrm{a}}$ ed. Rio de Janeiro:Lumem Júris, 2000. 142p.

PEREIRA, Caio Mário da Silva. Instituições de Direito Civil. 14 ${ }^{\mathrm{a}}$ ed.. Rio de Janeiro: Forense, 2004. 585 p.

PEREIRA, Jane Reis Gonçalves; LUCAS DA SILVA, Fernanda Duarte Lopes. "A estrutura normativa das normas constitucionais: notas sobre a distinção entre princípios e regras". In: PEIXINHO, Manoel Messias, et alii. Os princípios da Constituição de 1988. Rio de Janiero: Lumen Juris, 2001. 646p.

PEREIRA, Rodrigo da Cunha. Direito de Família Contemporâneo. Belo Horizonte: Del Rey, 1997. 835p.

PERLINGIERI, Pietro. Perfis do Direito Civil: Introdução ao Direito Civil Constitucional. $2^{\mathrm{a}}$.ed.. Rio de Janeiro: Renovar, 2002. 359 p.

RAMOS, Carmem Lucia Silveira. Família sem casamento: Da relação existencial de fato a realidade jurídica. Rio de Janeiro: Renovar, 2000. 193 p.

REALE, Miguel. Críticas apressadas ao novo Código Civil. RT: Revista dos Tribunais. Rio de Janeiro, 1998. $n^{\circ} .752 .87^{\circ}$. ano . 2000. 393p.

Lições preliminares de Direito. $25^{\mathrm{a}}$ ed.. São Paulo: Saraiva,

REDAÇÃO TERRA. Bush Volta a atacar casamento homossexual. Disponível em $<$ www.midiaindependente.org/em/blue/2004/01/273310.shtml $>$. Acesso em 30 de jan. 2005. 
RIBEIRO, Thaysa Halima. Adoção e sucessão nas células familiares homossexuais.

Equiparação à união estável. Disponível em $<$ www1.jus.com.br/doutrina/texto.asp?id=3790>. Acesso em 02 fev. 2005.

RIOS, Roger Raupp. O princípio da igualdade e da não discriminação por orientação sexual: a homossexualidade no Direito brasileiro e norteamericano. São Paulo: Revista dos Tribunais, 2002. 192 p.

RODRIGUES, Silvio. Direito Civil: Direito de Família. $26^{\text {a }}$.ed. São Paulo: Saraiva, 2003. 473p.

THOMAZ, Emma Ross. Espanha desafia Igreja e aprova casamento homossexual. Disponível em $<$ http://br.news.yahoo.com/050421/5/tj91.html>. Acesso em 25 de abr. 2005.

THOMAZ, Thiago Hauptmann Borelli. União homossexual: Reflexões jurídicas. Disponível em <www1.jus.com.br/doutrina/texto.asp?id=3930>. Acesso em 24 jan. 2005.

TITOIFF ADVOGADOS. União estável. Disponível em $<$ www.titoiff.adv.br/texto01.htm>. Acesso em 17 fev. 2005.

VENOSA, Silvio de Salvo. Direito Civil: Direito de Família. $4^{\text {a }}$.ed.. São Paulo: Atlas, 2004. $495 \mathrm{p}$.

VIANA, Marco Aurélio S.. Da união estável. São Paulo: Saraiva, 1999. 95 p.

YAHOO NOTÍCIAS. Parlamento da Nova Zelândia reconhece união civil gay. Disponível em <br.news.yahoo.com/041210/5/pvkh.html>. Acesso em 10 fev. 2005. 


\section{Anexo I}

\section{Projeto de Lei $n^{\circ} .1 .151 / 95$.}

Disciplina a união civil entre pessoas do mesmo sexo e dá outras providências.

O Congresso Nacional decreta:

Art. $1^{\circ}$ - É assegurado a duas pessoas do mesmo sexo o reconhecimento de sua união civil, visando a proteção dos direitos à propriedade, à sucessão e dos demais assegurados nesta Lei.

Art. $2^{\circ}$ - A união civil entre pessoas do mesmo sexo constitui-se mediante registro em livro próprio, nos Cartórios de Registro de Pessoas Naturais.

$\S 1^{\mathrm{o}}$ - Os interessados e interessadas comparecerão perante os oficiais de Registro Civil exibindo:

I - prova de serem solteiros ou solteiras, viúvos ou viúvas, divorciados ou divorciadas;

II - prova de capacidade civil plena;

III - instrumento público de contrato de união civil.

$\S 2^{\circ}$ - O estado civil dos contratantes não poderá ser alterado na vigência do contrato de união civil.

Art. $3^{\circ} \mathrm{O}$ contrato de união civil será lavrado em Ofício de Notas, sendo livremente pactuado. Deverá versar sobre disposições patrimoniais, 
deveres, impedimentos e obrigações mútuas.

Parágrafo único - Somente por disposição expressa no contrato, as regras nele estabelecidas também serão aplicadas retroativamente, caso tenha havido concorrência para formação do patrimônio comum.

Art. $4^{\circ}$ - A extinção da união civil ocorrerá:

I - pela morte de um dos contratantes;

II - mediante decretação judicial.

Art. $5^{\circ}$ - Qualquer das partes poderá requerer a extinção da união civil:

I - demonstrando a infração contratual em que se fundamenta o pedido;

II - alegando desinteresse na sua continuidade.

$\S 1^{\circ}$ - As partes poderão requerer consensualmente a homologação judicial da extinção da união civil.

$\S 2^{\circ}$ - O pedido judicial de extinção da união civil, de que tratam o inciso II e o $\S 1^{\circ}$ deste artigo, só será admitido após decorridos 2 (dois) anos de sua constituição.

Art. $6^{\circ}$ - A sentença que extinguir a união civil conterá a partilha dos bens dos interessados, de acordo com o disposto no instrumento público.

Art. $7^{\circ}$ - O registro de constituição ou extinção da união civil será averbado nos assentos de nascimento e casamento das partes. 
Art. $8^{\circ}$ É crime, de ação penal pública condicionada à representação, manter o contrato de união civil a que se refere esta lei com mais de uma pessoa, ou infringir o $\S 2^{\circ}$ do art. $2^{\circ}$

Pena - detenção de 6 (seis) meses a 2 (dois) anos.

Art. $9^{\circ}$ - Alteram-se os artigos da Lei 6.015, de 31 de dezembro de 1973, que passam a vigorar com as seguintes redações:

"Art. 33 - Haverá em cada cartório os seguintes livros, todos com trezentas folhas cada um:

III - B - Auxiliar - de registro de casamento religioso para efeitos civis e contratos de união civil entre pessoas do mesmo sexo.

Art. 167 - No Registro de Imóveis, além da matrícula, serão feitos:

I - o registro:

35 - dos contratos de união civil entre pessoas do mesmo sexo que versarem sobre comunicação patrimonial, nos registros referentes a imóveis ou a direitos reais pertencentes a qualquer das partes, inclusive os adquiridos posteriormente à celebração do contrato.

II - a averbação: 


\section{(...)}

14 - das sentenças de separação judicial, de divórcio, de nulidade ou anulação do casamento e de extinção de união civil entre pessoas do mesmo sexo, quando nas respectivas partilhas existirem imóveis ou direitos reais sujeitos a registro."

Art. 10 - O bem imóvel próprio e comum dos contratantes de união civil com pessoa do mesmo sexo é impenhorável, nos termos e condições regulados pela Lei 8.009, de 29 de março de 1990.

Art. 11 - Os artigos 16 e 17 da Lei 8.213, de 24 de julho de 1991, passam a vigorar com a seguinte redação:

"Art. $16(\ldots)$

$\S 3^{\circ}$. Considera-se companheiro ou companheira a pessoa que, sem ser casada, mantém com o segurado ou com a segurada, união estável de acordo com o parágrafo $3^{\circ}$ do art. 226 da Constituição Federal, ou união civil com pessoa do mesmo sexo nos termos da lei.

Art. 17 (..)

$\S 2^{\circ}$. O cancelamento da inscrição do cônjuge e do companheiro ou companheira do mesmo sexo se processa em face de separação judicial ou divórcio sem direito a alimentos, certidão de anulação de casamento, certidão de óbito ou sentença judicial, transitada em julgado".

Art. 12 Os artigos 217 e 241 da Lei 8.112, de 11 de dezembro de 1990, passam a vigorar com a seguinte redação: 
"Art. 217. (...)

c) a companheira ou companheiro designado que comprove a união estável como entidade familiar, ou união civil com pessoa do mesmo sexo, nos termos da lei.

Art. 241. (...)

Parágrafo único. Equipara-se ao cônjuge a companheira ou companheiro, que comprove a união estável como entidade familiar, ou união civil com pessoa do mesmo sexo, nos termos da lei."

Art. 13 - No âmbito da Administração Pública, os Estados, os Municípios e o Distrito Federal disciplinarão, através de legislação própria, os benefícios previdenciários de seus servidores que mantenham a união civil com pessoa do mesmo sexo.

Art. 14 - São garantidos aos contratantes de união civil entre pessoas do mesmo sexo, desde a data de sua constituição, os direitos à sucessão regulados pela Lei no 8.971, de 28 de novembro de 1994.

Art. 15 - Em havendo perda da capacidade civil de qualquer um dos contratantes de união civil ente pessoas do mesmo sexo, terá a outra parte a preferência para exercer a curatela.

Art. 16 - O inciso I do art. 113 da Lei 6.815, de 19 de agosto de 1980 passa a vigorar com a seguinte redação: 
"Art. 113. (..)

I - ter filho, cônjuge, companheira ou companheiro de união civil entre pessoas do mesmo sexo, brasileiro ou brasileira".

Art. 17 - Esta Lei entra em vigor na data de sua publicação.

Art. 18 - Revogam-se as disposições em contrário. 


\section{Anexo II}

\section{Substitutivo adotado pela Comissão.}

Projeto de Lei $n^{\circ} .1151 / 95$.

Disciplina a parceria civil registrada entre pessoas do mesmo sexo e dá outras providências.

O Congresso Nacional Decreta:

Art. 1o. É assegurado a duas pessoas do mesmo sexo o reconhecimento de sua parceria civil registrada, visando à proteção dos direitos à propriedade, à sucessão e aos demais regulados nesta Lei.

Art. 2o. A parceria civil registrada constitui-se mediante registro em livro próprio, nos Cartórios de Registro Civil de Pessoas Naturais na forma que segue.

$\S 10$. Os interessados comparecerão perante os Oficiais de Registro Civil, apresentando os seguintes documentos:

I. - declaração de serem solteiros, viúvos, ou divorciados;

II. - prova de capacidade civil absoluta, mediante apresentação de certidão de idade ou prova equivalente;

III. - instrumento público do contrato de parceria civil.

$\S 20$. Após a lavratura do contrato a parceria civil deve ser registrada em livro próprio no Registro Civil de Pessoas Naturais

$\S 30$. O estado civil dos contratantes não poderá ser alterado na vigência do contrato de parceria civil registrada. 
Art. 3o. O contrato de parceria registrada será lavrado em Ofício de Notas, sendo livremente pactuado e versando sobre disposições patrimoniais, deveres, impedimentos e obrigações mútuas.

$\S 1$ 10. Somente por disposição expressa no contrato, as regras nele estabelecidas também serão aplicadas retroativamente, caso tenha havido concorrência para formação de patrimônio comum.

$\S 2$ o. São vedadas quaisquer disposições sobre adoção, tutela ou guarda de crianças ou adolescentes em conjunto, mesmo que sejam filhos de um dos parceiros.

Art. 4o. A extinção da parceria registrada ocorrerá: I. - pela morte de um dos contratantes;

II. - mediante decretação judicial;

III. - de forma consensual, homologada pelo juiz.

Art. 5o. Qualquer das partes poderá requerer a extinção da parceria registrada:

I. - demonstrando a infração contratual em que se fundamenta o pedido; II. - alegando o desinteresse na sua continuidade.

Parágrafo único. As partes poderão requerer consensualmente a homologação judicial da extinção de sua parceria registrada.

Art. 6o. A sentença que extinguir a parceria registrada conterá a partilha dos bens dos interessados, de acordo com o disposto no contrato.

Art. 7o. É nulo de pleno direito o contrato de parceria registrada feito com mais de uma pessoa ou quando houver infração ao $§ 20$ do artigo 2o desta Lei.

Parágrafo único. Ocorrendo a infração mencionada no caput, seu autor 
comete o crime de falsidade ideológica, sujeitando-se às penas do artigo 299o do Decreto-Lei no 2.848, de 7 de dezembro de 1940.

Art. 8o. Alteram-se os arts. 29, 33 e 167 da Lei no 6.015, de 31 de dezembro de 1973, que passam a vigorar com as seguintes redações: "Art.29. Serão registrados no registro civil de pessoas naturais (...) IX - os contratos de parceria civil registrada entre pessoas do mesmo sexo. Parágrafo 1o. Serão averbados: (...)

g) a sentença que declarar e extinção da parceria civil registrada entre pessoas do mesmo sexo.

Art. 33. Haverá em cada cartório, os seguintes livros: (...)

III - E - de registro de contratos de parceria civil registrada entre pessoas do mesmo sexo.

Art. 167. No Registro de Imóveis, além da matrícula, serão feitos:

I - o registro:

(...)

35 - dos contratos de parceria civil registrada entre pessoas do mesmo sexo que versem sobre comunicação patrimonial, nos registros referentes a imóveis ou a direitos reais pertencentes a qualquer das partes, inclusive os adquiridos posteriormente à celebração do contrato.

II - a averbação:

(...)

14 - das sentenças de separação judicial, de divórcio, de nulidade ou anulação do casamento e de extinção de parceria civil registrada entre pessoas do mesmo sexo, quando nas respectivas partilhas existirem imóveis ou direitos reais sujeitos a registro."

Art. 9. O bem imóvel próprio e comum dos contratantes de parceria civil registrada entre pessoas do mesmo sexo é impenhorável, nos termos e condições regulados pela lei 8.009, de 29 de março de 1990. 
Art. 10. Registrado o contrato de parceria civil de que trata esta Lei, o parceiro será considerado beneficiário do Regime Geral de Previdência Social, na condição de dependente do segurado. Parágrafo único. A extinção do contrato de parceria implica o cancelamento da inscrição a que se refere o caput deste artigo.

Art. 11. O parceiro que comprove a parceria civil registrada será considerado beneficiário da pensão prevista no art. 217, I, da Lei 8.112, de 11 de dezembro de 1990.

Art. 12. No âmbito da Administração Pública, os Estados, os Municípios e o Distrito Federal disciplinarão, através de legislação própria, os benefícios providenciarias de seus servidores que mantenham parceria civil registrada com pessoa do mesmo sexo.

Art. 13. São garantidos aos contratantes de parceria civil registrada com pessoa do mesmo sexo, desde a data de sua constituição, os direitos à sucessão, nas seguintes condições:

I. - o parceiro sobrevivente terá direitos, desde que não firme novo contrato de parceria civil registrada, ao usufruto da quarta parte dos bens do de cujus, se houver filhos desde;

II. - o parceiro sobrevivente terá direito, enquanto não contratar nova parceria civil registrada, ao usufruto da metade dos bens do de cujus, se não houver filhos, embora não sobrevivam ascendentes;

III. - na falta de descendentes e ascendentes, o parceiro sobrevivente terá direito à totalidade da herança;

IV. - se os bens deixados pelo autor da herança resultar de atividade em que haja a colaboração do parceiro, terá o sobrevivente direito à metade dos bens.

Art. 14. O art. 454 da Lei 3071 , de $1^{\circ}$ de janeiro de 1916, passa a vigorar acrescido de $\S 3^{\circ}$, com a redação que se segue, passando o atual $\S 3^{\circ}$ a $\S 4^{\circ}$ : 
"Art. 454. (...)

$\S 1^{\circ}(\ldots)$

$\S 2^{\circ}(\ldots)$

$\S 3^{\circ}$ Havendo parceria civil registrada com pessoa do mesmo sexo, a esta se dará a curatela.

Art. 15. O art. 113 da Lei 6.815, de agosto de 1980, passa a vigorar com a seguinte redação:

"Art. 113.

(...)

VI - ter contrato de parceria civil registrada com pessoa de nacionalidade brasileira."

Art. 16. É reconhecido aos parceiros o direito de composição de rendas para aquisição da casa própria e todos os direitos relativos a planos de saúde e seguro de grupo.

Art. 17. Será admitida aos parceiros a inscrição como dependentes para efeitos de legislação tributária.

Art. 18. Esta Lei entra em vigor na data de sua publicação.

Art. 19. Revogam-se as disposições em contrário.

Sala da Comissão, em 10 de dezembro de 1996. 